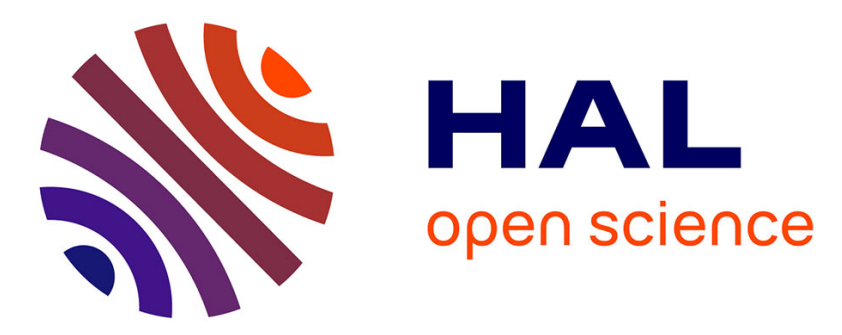

\title{
Kinetics and mechanism of reaction between water vapor, carbon monoxide and a chromia-forming nickel base alloy
}

Jérôme Chapovaloff, Fabien Rouillard, Krzysztof Wolski, Michèle Pijolat

\section{- To cite this version:}

Jérôme Chapovaloff, Fabien Rouillard, Krzysztof Wolski, Michèle Pijolat. Kinetics and mechanism of reaction between water vapor, carbon monoxide and a chromia-forming nickel base alloy. Corrosion Science, 2013, 69, pp.31-42. 10.1016/j.corsci.2012.09.045 . hal-00799717

\section{HAL Id: hal-00799717 https://hal.science/hal-00799717}

Submitted on 15 Mar 2013

HAL is a multi-disciplinary open access archive for the deposit and dissemination of scientific research documents, whether they are published or not. The documents may come from teaching and research institutions in France or abroad, or from public or private research centers.
L'archive ouverte pluridisciplinaire HAL, est destinée au dépôt et à la diffusion de documents scientifiques de niveau recherche, publiés ou non, émanant des établissements d'enseignement et de recherche français ou étrangers, des laboratoires publics ou privés. 


\title{
Kinetics and mechanism of reaction between water vapour, carbon monoxide and a chromia-forming nickel base alloy
}

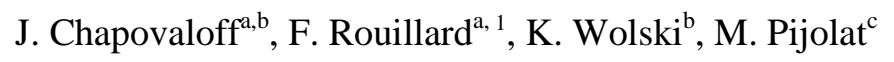 \\ ( $\left.{ }^{a}\right)$ CEA, DEN, DPC, SCCME, Laboratoire d'Etude de la Corrosion Non Aqueuse, \\ 91191 Gif sur Yvette, France \\ $\left(^{b}\right)$ Ecole Nationale Supérieure des Mines, Centre SMS, Département MPI, \\ LGF - CNRS UMR 5307, 158 Cours Fauriel, 42023 Saint Etienne, France \\ $\left({ }^{c}\right)$ Ecole Nationale Supérieure des Mines, Centre SPIN, Département PRESSIC, \\ LGF - CNRS UMR 5307, 158 Cours Fauriel, 42023 Saint Etienne, France
}

\begin{abstract}
The kinetic aspects of the competitive reaction of $\mathrm{CO}$ and $\mathrm{H}_{2} \mathrm{O}$ in the formation of chromia layer on a nickel base alloy at high temperature were studied by thermogravimetry combined to gas phase chromatography. It was shown that competitive adsorption occurred between both molecules and that whatever $\mathrm{P}_{\mathrm{CO}} / \mathrm{P}_{\mathrm{H} 2 \mathrm{O}}$ ratio, $\mathrm{CO}$ mainly reacted in the first instants of oxidation and $\mathrm{H}_{2} \mathrm{O}$ became the main long-term oxidant species. After an interfacial and diffusion mixed kinetic regime, the long-term oxidation rate was parabolic and did not depend on the water vapour content in the gas phase. The oxidation kinetics was well described by considering that the rate limiting step was the outwards diffusion of interstitial chromium cations in the oxide layer.
\end{abstract}

\section{Keywords}

A. Superalloys; C. High temperature Corrosion; C. Oxidation; C. Reactor conditions.

\footnotetext{
${ }^{1}$ Corresponding author. Tel.: +33 16908 1614; fax: +33 169081586

E-mail address: fabien.rouillard@cea.fr (F. Rouillard)
} 


\section{Introduction}

The understanding of high temperature corrosion of alloys in mixed gas environments containing aggressive species such as oxygen bearing species $\left(\mathrm{H}_{2} \mathrm{O}, \mathrm{CO}_{2}, \mathrm{O}_{2}, \mathrm{CO} \ldots\right)$, carbon bearing species $\left(\mathrm{CH}_{4}, \mathrm{CO}_{2}, \mathrm{CO} \ldots\right)$ or sulphur bearing species $\left(\mathrm{SO}_{2}, \mathrm{H}_{2} \mathrm{~S} \ldots\right)$ is more than ever, nowadays, a major research area. Progress is urgently needed since most of the future technologies involve complex environments. In prospective nuclear plants, High Temperature gas cooled Reactor (HTR) is one typical example of technologies involving the use of complex aggressive atmospheres. It is a nuclear system with an all graphite core cooled by helium. From reactions between the pollutants - out-gassing, air ingress - and the hot graphite core, the helium coolant contains a mixture of small amounts of impurities typically $\mathrm{H}_{2}, \mathrm{H}_{2} \mathrm{O}, \mathrm{CO}$, and $\mathrm{CH}_{4}$. Even if these impurities are highly diluted in helium - only between a few tens to hundreds of $\mu$ bar - they can react at high temperature, typically between $850^{\circ} \mathrm{C}$ and $1000^{\circ} \mathrm{C}$, with structural metallic materials. Gas-metal interactions involved in HTR heat exchangers have been discussed in numerous papers published in the past three decades [1-6] and more recently in France [7-14] and in the USA [15-17]. These works have demonstrated that depending on the composition of the chromia-former alloy, on the working temperature $\left(850-1000^{\circ} \mathrm{C}\right)$ and on the partial pressures of the various gas species in helium, two main behaviours could be distinguished: either a passive corrosion behaviour based on the formation of a stable, slow-growing, Cr-rich oxide layer on the surface or an active corrosion with the destruction of the surface oxide layer and the subsequent decarburization or carburization of the alloy [9]. In the passive region which is the behaviour desired for the material, it is very important to know what is the oxide growth mechanism and its kinetics in order to predict the component lifetime. It has been shown in [8] that the oxide layer is formed in the first instant of exposure by reactions with both $\mathrm{CO}$ and $\mathrm{H}_{2} \mathrm{O}$ and that these reactions are in competition. At longer times, it appears that $\mathrm{H}_{2} \mathrm{O}$ is the main oxidizing species. Nevertheless, up to now, several questions remain opened: What is the rate limiting step of the long term oxidation kinetics by $\mathrm{H}_{2} \mathrm{O}$ ? What are the different reaction steps of $\mathrm{CO}$ and $\mathrm{H}_{2} \mathrm{O}$ with the metallic surface which could explain the competition between both species in the formation of the first oxide layers? In order to progress on these questions, a very innovating facility was conceived: a thermobalance was coupled to a gas phase chromatograph in order to get both in-situ mass gain measurements and in situ measurements of each gas species' consumption [18]. From these data, the experimental reaction kinetics of $\mathrm{CO}$ and $\mathrm{H}_{2} \mathrm{O}$ with the metallic surface could be determined and a reaction mechanism with several steps (adsorption, dissociation, diffusion...) could be proposed for each gas species.

\section{Experimental procedure}

\section{Material}

The chemical composition of the tested alloy 617 is given in Table 1 . Specimens of $15 \times 15 \mathrm{~mm}^{2}$ were machined from a metal sheet of $2 \mathrm{~mm}$ thickness. The specimen surfaces were ground to 2400-grit emery paper and finished with a diamond suspension of $3 \mu \mathrm{m}$. Before testing, they were washed ultrasonically in acetone, then alcohol, dried and weighed. 


\section{Test facility}

In order to make a well-controlled mixture of $\mathrm{CO}, \mathrm{H}_{2}$ and $\mathrm{H}_{2} \mathrm{O}$ in the $\mu$ bar range, a bottle of helium containing a low concentration of $\mathrm{CO}$ and a bottle a helium containing a low concentration of $\mathrm{H}_{2}$ were diluted into a main flow of pure helium via parallel mass flow meters. Then, in order to remove any oxygen and water vapour from the gas phase, the impure helium flow was passed through graphite packed in a quartz tube and heated within a furnace up to $900{ }^{\circ} \mathrm{C}$. The reaction of oxygen and water with graphite produced $\mathrm{CO}$ and $\mathrm{H}_{2}$. Finally, the water level was adjusted by passing through a container with temperature-controlled deaerated water. The exact amounts of $\mathrm{CO}, \mathrm{H}_{2}$ and $\mathrm{H}_{2} \mathrm{O}$ in the gas mixture were accurately measured by a gas phase chromatograph and a mirror chilled dew point hygrometer before injection in the thermobalance.

The measurements of the sample weight mass gain were carried out in a symmetric thermobalance whose accuracy was in the microgram range. The rates of gas production or consumption were measured by the gas phase chromatograph (GPC) every seven minutes at the thermobalance exit. The detection limit was $0.1 \mu$ bar. The facility is shown in Figure 1.

\section{Test conditions}

Corrosion tests under hydrogen enriched helium with different amounts of $\mathrm{CO}$ and $\mathrm{H}_{2} \mathrm{O}$ were carried out at $850^{\circ} \mathrm{C}$. Before reaching the temperature of interest $\left(20^{\circ} \mathrm{C} / \mathrm{min}\right)$, a plateau at $650^{\circ} \mathrm{C}$ for $2 \mathrm{~h}$ was carried out in order to desorb gases from the sample. Then, the temperature was increased up to $850^{\circ} \mathrm{C}$ at $1.7{ }^{\circ} \mathrm{C} / \mathrm{min}$. Two different test campaigns were carried out. First, the influence of the water vapour pressure on the corrosion kinetics was studied by varying its amount from $2 \mu$ bar to $21 \mu$ bar in a mixture composed of $14 \mu$ bar $\mathrm{CO}, 130 \mu$ bar $\mathrm{H}_{2}$ in helium $\left(\mathrm{He}-14 \mathrm{CO}-130 \mathrm{H}_{2}\right)$. Then the influence of the carbon monoxide pressure on the corrosion kinetics was studied by varying its amount from $7 \mu$ bar to $60 \mu$ bar in a mixture $\mathrm{He}-5 \mathrm{H}_{2} \mathrm{O}-130 \mathrm{H}_{2}$. In all experiments, the gas flow was accurately set to $43 \mathrm{~L} / \mathrm{h}$. Characterization of the corrosion layer was carried out by XRD, FESEM-EDX and GDOES.

\section{Experimental results}

\section{In-situ measurements of mass gains and GPC measurements}

The mass gain increase and the changes of the levels of gaseous impurities in helium atmosphere during the oxidation test of alloy 617 under $\mathrm{He}-14 \mathrm{CO}-130 \mathrm{H}_{2}$ with low water vapour partial pressure (4 $\mu$ bars) are shown in Figure 2. The gas phase analyses resulted from a mass balance performed between the output and the input measurements of the thermobalance. This was obtained, on one hand, by GPC for carbon monoxide and hydrogen and, on the other hand, by measurements on the chilled-mirror dew point hygrometer for the water vapour. Depending on whether the content variation was positive or negative, the gaseous impurities were respectively either produced or consumed by the sample.

As shown in Figure 2, during the temperature increase up to $850^{\circ} \mathrm{C}$, water vapour was consumed and hydrogen was produced symmetrically. $\mathrm{CO}$ was consumed as well but at much lower extent than water vapour. It started to be consumed at a higher temperature than water and its maximum consumption rate was reached at $850^{\circ} \mathrm{C}$. Once reached the temperature, the production rate of hydrogen and the consumption rate of water and carbon monoxide started to decrease with time. After $7 \mathrm{hrs}$, the consumption rate of $\mathrm{CO}$ was nearly null whereas the consumption rate of water and the production rate of hydrogen were still non negligible until the end of the test. 
They became null only during the temperature decrease. The fact that the evolution of the water consumption and the hydrogen production were symmetric strongly indicated that the sample oxidized by $\mathrm{H}_{2} \mathrm{O}$ according to reaction (1):

$$
x \mathrm{M}+y \mathrm{H}_{2} \mathrm{O} \rightarrow \mathrm{M}_{x} \mathrm{O}_{y}+y \mathrm{H}_{2}
$$

The $\mathrm{CO}$ consumption indicated that $\mathrm{CO}$ reacted with the sample surface according to reaction (2):

$$
x \mathrm{M}+y C O \rightarrow \mathrm{M}_{x} \mathrm{O}_{y}+y \mathrm{C}_{\mathrm{s}}
$$

with $\mathrm{C}_{\mathrm{s}}$, the carbon in solution. We consider in (2) that carbon was deposited in solution in the sample since no solid phases such as carbides could be observed.

\section{Mass balance}

In order to check if the experimental mass gain observed on the sample was entirely due to reaction (1) and (2), the theoretical mass gain considering (1) and (2) and the GPC analyses were calculated and compared.

Figure 3 shows $\mathrm{m}(\mathrm{O})_{\mathrm{H} 2}$, the mass gain calculated from the $\mathrm{H}_{2}$ production measured by GPC (indicating the $\mathrm{H}_{2} \mathrm{O}$ consumption through reaction $(1)), \mathrm{m}(\mathrm{O})_{\mathrm{CO}}$, the mass gain calculated from the $\mathrm{CO}$ consumption measured by GPC and reaction (2), the total mass gain from both $\mathrm{CO}$ and $\mathrm{H}_{2} \mathrm{O}$ and the experimental mass gain measured by thermobalance. Figure 3 shows that the total mass gain from both $\mathrm{CO}$ and $\mathrm{H}_{2} \mathrm{O}$ was in very good agreement with the experimental mass gain. As a consequence the total mass gain was exclusively due to reactions (1) and (2) during the whole corrosion test duration.

One very important result that should be observed in Figure 3 is that more than $90 \%$ of the total mass gain was due to oxidation by $\mathrm{H}_{2} \mathrm{O}$ even if its partial pressure was about 3 times lower than the partial pressure of CO.

\section{Surface observations}

Figure 4 shows the oxide layer formed on alloy 617 surface after the corrosion test at $850^{\circ} \mathrm{C}$ for $20 \mathrm{hrs}$ under He$14 \mathrm{CO}-130 \mathrm{H}_{2}-4 \mathrm{H}_{2} \mathrm{O}$. It can be observed that the oxide morphology was heterogeneous. The oxide which grew above the metallic grains was mainly made of small crystallites whereas the oxide formed above the metallic grain boundaries were thicker and with a foam-like morphology. Complementary characterizations of the surface by XRD, GDOES and FESEM-EDX revealed that the oxide layer was mainly made of $\mathrm{Cr}_{2} \mathrm{O}_{3}$ with an upper layer enriched in $\mathrm{Mn}$ (XRD pattern: $\mathrm{Mn}_{1.5} \mathrm{Cr}_{1.5} \mathrm{O}_{4}$ ) and titanium. From Figure 4, the oxide layer thickness reached about $300 \mathrm{~nm}$ but could reach more than $1 \mu \mathrm{m}$ above the metallic grain boundaries. Below the oxide layer, several voids condensed at the metal/oxide interface and in metallic grain boundaries. Aluminium rich intergranular oxides precipitated in metallic grain boundaries up to several microns in depth. EDX analysis combined with GDOES profiling of the oxide layer revealed silicon enrichment at the metal/oxide interface. Since this element is well-known for segregating from the very first instants of oxidation [8], it could be proposed that the oxide/metal interface corresponded more or less to the initial metallic surface. As a consequence, the growth of chromia layer was likely to be mainly outwards. This proposition is in good agreement with the observation of voids deeper in the alloy which could result from vacancies condensation [19]. 


\section{Influence of $\mathrm{CO}$ content on its consumption rate}

Figure 5 shows the $\mathrm{CO}$ consumption over time for corrosion tests with different amount of CO from 7 to $60 \mu$ bar in $\mathrm{He}-130 \mathrm{H}_{2}-5 \mathrm{H}_{2} \mathrm{O}$. The hydrogen production (which indicated the reaction rate of water) and the mass gain were roughly the same whatever the $\mathrm{CO}$ amount used in the corrosion tests. First, it could be observed that when the $\mathrm{CO}$ partial pressure increased in impure helium, the maximum $\mathrm{CO}$ consumption rate defined at point $\mathrm{B}$, ie when $850^{\circ} \mathrm{C}$ was reached, increased. Then, during the plateau at $850^{\circ} \mathrm{C}$, the consumption rate decreased with time and tended to zero except for the highest $\mathrm{CO}$ partial pressure at $60 \mu$ bar since the consumption started again after 13h. This new consumption was not explained.

With $7 \mu$ bars, $14 \mu$ bars, $28 \mu$ bars and $60 \mu$ bars of CO, the percentage of the total mass gain of the sample due to reaction with $\mathrm{CO}$ was $3 \%, 8 \%, 8.5 \%$ and $11 \%$ respectively. Thus, even for a CO partial pressure more than 12 times higher than the water partial pressure, the $\mathrm{CO}$ consumption stayed a minor process. Finally, no major difference in the oxide morphology could be observed when changing the $\mathrm{CO}$ partial pressure in the corrosion tests.

\section{Influence of the water content in helium on the maximum rate of $\mathrm{CO}$ consumption}

In Figure 6 is shown the maximum rate of $\mathrm{CO}$ consumption as a function of water content in $\mathrm{He}-14 \mathrm{CO}-130 \mathrm{H}_{2}$. It could be observed that when the water content increased in the gas phase, the maximum CO consumption rate decreased. Moreover when the water content was set higher than $17 \mu \mathrm{bar}$, CO did not react any more. The observations in Figure 5 and Figure 6 that the $\mathrm{CO}$ consumption depended both on $\mathrm{CO}$ partial pressure and $\mathrm{H}_{2} \mathrm{O}$ partial pressure in the gas phase suggests that there was a competition between both reactions probably linked to the adsorption steps or interfacial reactions. The rate limiting step will be discussed next. Another important result was that $\mathrm{CO}$ reaction occurred only in the first hours and was, thus, transient. $\mathrm{H}_{2} \mathrm{O}$ was the main oxidant species both for short and long-term exposure.

\section{Influence of the water content on the oxide growth rate}

Figure 7 shows the mass gain of alloy 617 measured in-situ by thermobalance in $\mathrm{He}-14 \mathrm{CO}-130 \mathrm{H}_{2}$ as a function of the water content in helium. It could be observed that the oxide growth kinetics was in all cases parabolic and that the oxide growth rate increased with the water partial pressure in helium.

\section{Discussion}

\section{Modelling of the $\mathrm{CO}$ consumption kinetics}

The study on the carbon monoxide consumption by alloy 617 showed that its maximum consumption (indicated by point B on the GPC analysis in Figure 5) was sensitive to the impure helium composition. The different corrosion tests showed that it decreased when the partial pressure of carbon monoxide decreased (see Figure 5) or when the partial pressure of water vapour increased (see Figure 6). To model the consumption kinetics of carbon monoxide it is necessary, first, to write the reaction mechanism, then, to know the limiting step of the kinetics, that is to say the elementary step which had the lowest rate constant. In most cases, diffusion phenomena are those with the lowest rate constants, but sometimes the interfacial processes play an important role, especially for thin oxide scale such as the one encountered in the first instants of oxide growth. To model 
the kinetics of consumption of carbon monoxide at point B (which corresponds to the maximum rate of consumption), let consider a chemical sorption process on the external oxide layer surface able to describe the competition between water vapour and carbon monoxide.

The most common model of adsorption is to consider that the gas molecule bound to a site on the surface without creating a new adsorption site (Langmuir's theory [20]). Then, these species could form other species which were likely to be desorbed. For water molecule, let consider four different steps which may have occurred on the oxide surface. To express the equilibrium constants of reactions $\left(\mathrm{K}_{\mathrm{eq}}\right)$ in the case of monolayer adsorption, let consider the recovery factor $\theta_{i}=\frac{s_{i}}{s_{0}}$ as variable where $\mathrm{s}_{0}$ is the initial concentration of available sites per area unit and $\mathrm{S}_{\mathrm{i}}$, the concentration of sites of sites occupied by species i per area unit.

For adsorption and dissociation of $\mathrm{H}_{2} \mathrm{O}$ and $\mathrm{CO}$, the following reaction steps with their equilibrium constants are proposed in Table 2.

\begin{tabular}{|c|c|c|c|}
\hline Semi reaction & & Equilibrium constant & \\
\hline $\mathrm{H}_{2} \mathrm{O}+\mathrm{s} \stackrel{k_{1}}{\longrightarrow} \mathrm{H}_{2} \mathrm{O}-\mathrm{S}$ & (3) & $K_{e q .}^{S I}=\frac{\theta \mathrm{H}_{2} \mathrm{O}-s}{\theta_{s} \cdot \mathrm{PH}_{2} \mathrm{O}}$ & $(10)$ \\
\hline $\mathrm{H}_{2} \mathrm{O}-\mathrm{s}+\mathrm{s} \stackrel{k_{2}}{\longrightarrow} \mathrm{HO}-\mathrm{s}+\mathrm{H}-\mathrm{s}$ & (4) & $K_{e q .}^{s 2}=\frac{\theta H O-s \cdot \theta H-s}{\theta_{s} \cdot \theta_{H_{2}} \mathrm{O}-s}$ & $(11)$ \\
\hline $2 \mathrm{H}-\mathrm{s} \stackrel{k_{3}}{\longrightarrow} \mathrm{H}_{2}+2 \mathrm{~s}$ & $(5)$ & $K_{e q .}^{S 3}=P H_{2} \cdot\left(\frac{\theta_{s}}{\theta H-s}\right)$ & $(12)$ \\
\hline$H O-s+s \stackrel{k_{4}}{\longrightarrow} H-s+O-s$ & (6) & $K_{e q .}^{S 4}=\frac{\theta O-s \cdot \theta H-s}{\theta_{s} \cdot \theta H O-s}$ & $(13)$ \\
\hline Semi reaction & & Equilibrium constant & \\
\hline $\mathrm{CO}+\mathrm{s} \stackrel{k_{5}}{\longrightarrow} \mathrm{CO}-\mathrm{s}$ & (7) & $K_{e q .}^{S 5}=\frac{\theta C O-s}{\theta_{s} \cdot P C O}$ & (14) \\
\hline$C O-s+s \stackrel{k_{6}}{\longrightarrow} C-s+O-s$ & (8) & $K_{e q .}^{s 6}=\frac{\theta_{C-s} \cdot \theta_{O-s}}{\theta_{s} \cdot \theta C O-s}$ & $(15)$ \\
\hline$C-s \stackrel{k_{7}}{\longrightarrow} C+s$ & (9) & $K_{e q .}^{S 7}=\frac{\theta_{s} \cdot a_{C}}{\theta C-s}$ & $(16)$ \\
\hline
\end{tabular}

with $\mathrm{k}_{\mathrm{i}}$ the constant rates of the elemental semi reaction. 
Oxygen adsorbed on the surface of the oxide layer (O-s) from both $\mathrm{H}_{2} \mathrm{O}$ (reaction 6) and $\mathrm{CO}$ (reaction 8) participates in the growth of the oxide layer and releases the adsorption site s. Hydroxyl species $\mathrm{OH}^{\circ}$, often presented in the literature was only considered, here, as an non stable intermediate species and do not participate to the edification of the oxide layer. This assumption is in good agreement with Lu et al.'s observation that the $\mathrm{OH} / \mathrm{O}$ ratio in the oxide layer formed on pure chromium at $450^{\circ} \mathrm{C}$ was lower than 0.1 [21]. Moreover, considering $\mathrm{CO}$ adsorption, we preferred to consider as first reaction a "deposit" of pure carbon on the surface of the oxide layer. Then, it is conceivable to expect other basic steps where carbon formed chromium oxy-carbide or dissolved in the oxide. But all these steps were not described here since they were not assumed to be rate limiting in the mechanism of oxidation by $\mathrm{CO}$.

From Eyring's theory, the order coefficient for each species involved in elementary reactions is equal to the stoichiometric factor of the species and is null for normal constituent of the unit cell or the metallic phase [22]. If one considers, now, one after the other, each adsorption/dissociation steps as rate limiting (and neglecting the reverse side of each reaction since they are considered to be far from the equilibrium), the rate laws which can rightly describe a decrease in $\mathrm{CO}$ consumption when the partial pressure of $\mathrm{H}_{2} \mathrm{O}$ increases or when the partial pressure of $\mathrm{CO}$ reduces are shown in Table 3.

\section{$\mathrm{CO}+\mathrm{s} \stackrel{k_{7}}{\longrightarrow} \mathrm{CO}-\mathrm{s}$}

$$
v_{7}=k_{7} \cdot \theta s . P C O
$$

By writting $\theta s$ as a function of the equilibrium constants of the other elemental steps and by using equation 8 below:

$$
\theta \mathrm{H}_{2} \mathrm{O}-\mathrm{S}+\theta H \mathrm{H}-\mathrm{S}+\theta \mathrm{H}-\mathrm{s}+\theta \mathrm{O}-\mathrm{s}+\theta \mathrm{s}+\theta \mathrm{CO}-\mathrm{s}+\theta \mathrm{C}-\mathrm{s}=1
$$

one ends up with

$$
\begin{gathered}
\boldsymbol{v}_{7}=\boldsymbol{k}_{7} \cdot \frac{\boldsymbol{P C O} \cdot \boldsymbol{\alpha}}{\boldsymbol{P H}_{2} \boldsymbol{O} \cdot \boldsymbol{\beta} \cdot \boldsymbol{\gamma}} \\
\alpha=K_{e q .}^{R .8} \cdot K_{e q .}^{R .9} \cdot \sqrt{K_{e q .}^{R .5}} \cdot P H_{2} \\
\gamma=K_{e q .}^{R .8} \cdot \sqrt{K_{e q .}^{R .5}} \cdot \sqrt{P H_{2}}\left(K_{e q .}^{R .9} \cdot \sqrt{P H_{2}}+a_{C}\right)
\end{gathered}
$$




$$
\begin{aligned}
& \alpha=\frac{1}{K_{e q .}^{R .9}} \quad \beta=\frac{K_{e q .}^{R .3}}{K_{e q .}^{R .7} \cdot K_{e q .}^{R .9} \cdot P H_{2}}\left(K_{e q .}^{R .4} \cdot K_{e q .}^{R .5} \cdot K_{e q .}^{R .6}+\sqrt{K_{e q .}^{R .5}} \cdot K_{e q .}^{R .4} \cdot \sqrt{P H_{2}}+P H_{2}\right) \\
& \gamma=\frac{K_{e q .}^{R .9} \cdot \sqrt{K_{e q .}^{R .5}}+a_{C} \cdot \sqrt{K_{e q .}^{R .5}}+K_{e q .}^{R .9} \cdot \sqrt{P H_{2}}}{K_{e q .}^{R .7} \cdot\left(K_{e q .}^{R .9}\right)^{2} \cdot \sqrt{K_{e q .}^{R .5}}}
\end{aligned}
$$

The comparison between the experimental results and the two equations (18) and (19) shows in Figure 8 that the most appropriate rate limiting step to describe the observed changes of the maximum rate of CO consumption (point B) as a function of water and carbon monoxide partial pressures is the CO dissociation (reaction (7) with equation (18)).

Water vapour, which was responsible for more than $90 \%$ of oxidation, decreased the coverage in free sites $\theta_{\mathrm{s}}$ on the outer oxide surface which resulted in decreasing the amount of dissociated carbon monoxide per unit time on the surface of the oxide layer (Figure 8). This competition between $\mathrm{H}_{2} \mathrm{O}$ and $\mathrm{CO}$ on adsorption sites was also observed by Anghel et al. when studying CO dissociation on chromium oxide [23]. Indeed, they observed that $\mathrm{CO}$ dissociation decreased by increasing the partial pressure of water in the gas phase. They concluded that $\mathrm{H}_{2} \mathrm{O}$ had a higher tendency for molecular adsorption than $\mathrm{CO}$ and, as a consequence, blocked reaction surface centers for $\mathrm{CO}$ reaction. Our results confirmed their results.

\section{Modelling of the $\mathrm{H}_{2} \mathrm{O}$ consumption kinetics}

Since the total mass gain measured by thermobalance was due to reaction with $\mathrm{H}_{2} \mathrm{O}$ for more than $90 \%$ whatever the CO partial pressure in impure helium, the total mass gain measured by thermobalance could be considered to characterize the reaction of the sample with $\mathrm{H}_{2} \mathrm{O}$. As a consequence, Figure 7 shows that the oxidation rate by $\mathrm{H}_{2} \mathrm{O}$ looks parabolic which means that the rate limiting step was probably diffusional. However, as reminded by several authors [24-27], the growth of an oxide layer controlled by pure diffusional process is generally a borderline case and it is most common to obtain kinetics that deviates slightly from theoretical behaviour especially in case of very thin oxide films. Mixed kinetic law introducing both a diffusion step $\left(\mathrm{k}_{\mathrm{p}}\right)$ and an interfacial step $\left(\mathrm{k}_{1}\right)$ is generally more appropriate to define the growth of an oxide layer [24-27]. After several assumptions and calculi (see Appendix A), the mixed kinetic law could be written as following:

$$
A m^{2}+B m+C=t
$$

where the values of parameters $A, B$ and $C$ given in the second-order polynomial expression are shown in Table

\section{A.1 (Appendix A).}

The fitting of the experimental curves by equation (20) with A and B forced to be positive constants (C can be either positive or negative) was satisfying only in the oxidation test carried out under low water vapor partial pressure (4 $\mu$ bar, Figure 9). The values of A, B and C were in that case equal to 116230,11762 and 106.43 respectively. When the partial pressure of water was higher, typically $21 \mu \mathrm{bar}, \mathrm{B}$ was found to be null (in order 
to obtain the best fit for the experimental curve) which meant that, in that case, the interfacial rate constant $\mathrm{k}_{1}$ was far higher than the parabolic rate constant $\mathrm{k}_{\mathrm{p}}$ and thus the oxidation rate follows the parabolic law.

As a consequence, with this kinetic model, the growth of the oxide layer under $4 \mu$ bars water vapour would be controlled by a mixed kinetic regime with a diffusion and interfacial step. In that case, the $k_{p}$ value and the $k_{l}$ value were found to be equal to $8,6 \cdot 10^{-6} \mathrm{mg} \cdot \mathrm{cm}^{-4} \cdot \mathrm{min}^{-1}$ and $8 \cdot 5 \cdot 10^{-5} \mathrm{mg} \cdot \mathrm{cm}^{-2} \cdot \mathrm{min}^{-1}$ respectively. At $\mathrm{H}_{2} \mathrm{O}$ partial pressures higher than $21 \mu$ bars, the kinetics could be considered as purely diffusional. The transition between these two kinetic models as a function of the water vapour content implies first, that the rate limiting interfacial step was dependent on the amount of water vapour and secondly, that the rate of the interfacial reaction increased rapidly with the amount of water vapour so that it was no longer limiting the growth of the oxide layer at high content of water vapour. This effect was only true in the first time of oxidation when the first tens or hundreds of nanometers of the oxide layer were built. The variation of the parabolic constant $\left(\mathrm{k}_{\mathrm{p}}\right)$ determined from the mixed kinetic model as a function of water vapour content is presented in Figure 10. Despite a poor reproducibility, it can be inferred that the parabolic constant does not vary with $\mathrm{H}_{2} \mathrm{O}$ partial pressure.

On the contrary of $\mathrm{k}_{\mathrm{p}}$ variations with $\mathrm{H}_{2} \mathrm{O}$ partial pressures, the linear rate constant $\mathrm{k}_{1}$ was found to increase significantly (Figure 11).

In order to write the proper reaction mechanism describing the external growth of the oxide layer on alloy 617 , the dominant point defect in the oxide layer should be determined. For outwards oxide growth (Figure 4), two defects must be considered: chromium vacancy $\left(\mathrm{V}_{\mathrm{Cr}}\right)$ and chromium interstitial $\left(\mathrm{Cr}_{\mathrm{i}}\right)$. On one hand, if the main defect was chromium vacancy, the parabolic rate constant would depend on the partial pressure of water since the interface of formation would be at the oxide/gas interface [28]. On the other hand, if the main defect was chromium interstitial, the parabolic rate constant would not depend on the partial pressure of water since the interface of formation would be at the oxide/metal interface [28]. These two cases are represented in Figure 12. Since it was observed that the parabolic rate constant did not depend on the partial pressure of water (Figure 10), the main point defect responsible for the outward oxide growth was most likely interstitial chromium ions.

The growth mechanism of the oxide layer assumed to be chromia could be divided into four basic steps which are schematized in Figure 13:

- $\quad$ The surface steps associated to water adsorption and hydrogen desorption at $\mathrm{Cr}_{2} \mathrm{O}_{3}$ surface (external surface steps)

The possible reactions of water adsorption on the oxide layer surface were detailed previously through reaction (3) to (6).

- $\quad$ The formation of interstitial chromium cations at the metal/oxide interface (internal interfacial step). When chromium metal was incorporated into the oxide as $\mathrm{Cr}_{i}^{\circ}$ (according to the Kroger-Vink notation [29]), a vacancy wascreated in the underlying metal and electrons were injected for electrical neutrality. The reaction could be written as following:

$$
\left(\mathrm{Cr}_{\mathrm{Cr}}^{\mathrm{X}}\right)_{\text {alloy }} \stackrel{\mathrm{k}_{21}}{\longrightarrow}\left(\mathrm{Cr}_{\mathrm{i}}^{\cdots \cdot}\right)_{\text {int }}+\left(\mathrm{V}_{\mathrm{Cr}}^{\mathrm{X}}\right)_{\text {alloy }}+3 \mathrm{e}^{\prime}
$$




$$
\text { with } K_{e q}^{21}=\frac{a_{C r_{i}^{\circ 00}} a_{V_{C r}^{X}}\left[e^{\prime}\right]^{3}}{a_{C r}}
$$

Considering that the activity of point defects in the oxide layer was equal to their concentration, $K_{e q}^{21}$ could be rewritten as:

$$
K_{e q .}^{21}=\frac{\left[C r_{i}^{\cdots \cdots}\right]_{i n t} \cdot\left[V_{C r}^{X}\right]_{\text {alloy }} \cdot\left[e^{\prime}\right]^{3}}{a_{C r}}
$$

Then, the vacancy condensation induced void formation under the oxide layer according to the following reaction:

$$
\begin{gathered}
\mathrm{n}\left(\mathrm{V}_{\mathrm{Cr}}^{\mathrm{X}}\right)_{\text {alloy }} \stackrel{\mathrm{k}_{24}}{\longrightarrow} \text { null }(\rightarrow \text { voids }) \\
\text { with }\left(K_{e q}^{24}\right)^{1 / n}=\frac{1}{\left[V_{C r}^{X}\right]_{\text {alloy }}}
\end{gathered}
$$

It would explain the observations of voids below oxide layer in Erreur ! Source du renvoi introuvable.

- The outwards diffusion of chromium interstitials through the oxide layer.

Interstitial chromium cations diffused from the metal/oxide interface to the gas/oxide interface.

$$
\left(\mathrm{Cr}_{\mathrm{i}}^{\cdots}\right)_{\mathrm{int}} \cdots>\left(\mathrm{Cr}_{\mathrm{i}}^{\cdots}\right)_{\mathrm{ext}}
$$

This step represents the only diffusion process in the oxidation mechanism.

- The reaction of chromium interstitial with adsorbed oxygen at the gas/oxide interface to form a new oxide unit cell (external interfacial reaction).

$$
\begin{gathered}
2\left(\mathrm{Cr}_{\mathrm{i}}^{\cdots}\right)_{\text {ext }}+3 \mathrm{O}-\mathrm{s}+6 \mathrm{e}^{\prime} \stackrel{\mathrm{k}_{27}}{\longrightarrow} 2\left(\mathrm{Cr}_{\mathrm{Cr}}^{\mathrm{X}}\right)_{\text {oxide }}+3\left(\mathrm{O}_{\mathrm{O}}^{\mathrm{X}}\right)_{\text {oxide }}+3 \mathrm{~s} \\
\text { avec } K_{\text {eq. }}^{27}=\frac{1}{\left[C r_{i}^{\cdots}\right]_{\text {ext }}^{2} \cdot\left[e^{\prime}\right]^{6}} \cdot\left(\frac{\theta_{s}}{\theta_{\text {o-s }}}\right)^{3}
\end{gathered}
$$

The global oxidation reaction of alloy 617 by water (29) was obtained by the linear combination of the different reaction steps as following: $3 *$ reaction (3) $+3 *$ reaction (4) $+3 *$ reaction $(5)+3 *$ reaction $(6)+2 *$ reaction $(21)+$ $2 *$ reaction $(24)+($ S27) , which results in: 


$$
\begin{gathered}
3 \mathrm{H}_{2} \mathrm{O}+2\left(\mathrm{Cr}_{\mathrm{Cr}}^{\mathrm{X}}\right)_{\text {alloy }} \longrightarrow 2\left(\mathrm{Cr}_{\mathrm{Cr}}^{\mathrm{X}}\right)_{\text {oxide }}+3\left(\mathrm{O}_{\mathrm{O}}^{\mathrm{X}}\right)_{\text {oxide }}+3 \mathrm{H}_{2} \\
\text { with } K_{\text {eq. }}^{29}=\frac{1}{a_{\mathrm{Cr}}} \cdot\left(\frac{P_{\mathrm{H}_{2}}}{P_{\mathrm{H}_{2} \mathrm{O}}}\right)^{3}=\left(K_{\text {eq. }}^{5} \cdot K_{\text {eq. }}^{6} \cdot K_{\text {eq. }}^{7} \cdot K_{\text {eq. }}^{8}\right)^{3} \cdot\left(K_{\text {eq. }}^{21}\right)^{2} \cdot\left(K_{\text {eq. }}^{24}\right)^{2 / n} \cdot K_{\text {eq. }}^{27}
\end{gathered}
$$

\section{Rate of the diffusion step}

From the oxidation mechanism proposed above, the only diffusion step was the diffusion of chromium interstitials from the metal/oxide interface to the gas/oxide interface.

Its rate could be expressed as following:

$$
v_{\text {dif. }}=\frac{D C r_{i}^{\cdots}}{X(t)} \cdot\left[C r_{i}^{\cdots \cdot}\right]_{i n t} \cdot S
$$

where $D_{C r}{ }^{\circ 0}$ is the chromium diffusion coefficient in the oxide layer, $X(t)$ the oxide layer thickness and $\mathrm{S}$, the oxide area that is taken equal to $1 \mathrm{~cm}^{2}$.

Photoelectrochemical measurements of the chromium rich oxide conductivity formed on alloy 617 have shown that the semi-conductivity was n-type which means electrons were the predominant electronic species. Work on model alloys with the same composition as alloy 617 with and without titanium have shown that titanium dissolved in the chromium rich oxide layer and that its semi-conductivity changed from p-type to n-type [30]. This in good accordance with previous results concluding that titanium (+4) dissolved in chromia adds excendentary mobile electrons [31]. As a consequence, we considered the following Brouwer approximation for the electroneutrality conservation equation in the oxide layer :

$$
\left[e^{\prime}\right]=\left[T \ddot{i}_{C r}\right]
$$

By expressing $\left[\mathrm{Cr}_{i}^{\cdots \cdot}\right]_{\text {int }}$ from steps (21) and (24) and combining Eq. (31) with Eq. (32), the expression of the diffusion rate becomes:

$$
v_{\text {dif }}=\frac{S \cdot D C_{i}^{-\cdots}}{X(t) \cdot\left[T i_{C r}^{\prime}\right]^{3}} \cdot\left(K_{e q .}^{21}\right) \cdot\left(K_{e q .}^{24}\right)^{1 / n} \cdot\left(a_{C r}\right)_{\text {alloy }}
$$

Finally, by combining Eq. (33) and Eq. (A.2) (see Appendix A), it results that the parabolic kinetic constant did not depend on the partial pressure of water:

$$
k_{p}=\frac{2 m \cdot S \cdot D C r_{i}^{-\prime}}{X(t) \cdot\left[T i_{C r}^{\prime}\right]^{3}} \cdot\left(K_{e q .}^{2 l}\right) \cdot\left(K_{e q .}^{24}\right)^{1 / n} \cdot\left(a_{C r}\right)_{\text {alloy }}
$$


This result is in good agreement with what was observed experimentally in Figure 10.

\section{Rate of the interfacial step}

The variation of the linear rate constant $\mathrm{k}_{\mathrm{l}}$ with the partial pressure of water that was observed experimentally indicates that the rate limiting step must have occurred at the gas/oxide interface. Since the adsorption step was not rate limiting neither for $\mathrm{CO}$ nor for $\mathrm{H}_{2} \mathrm{O}$ (it is not possible to get such dependency law by considering only steps (3) to (6) or (7) to (9)), the rate limiting step was likely to be the interfacial step (35) which corresponds to the formation of an oxide unit cell:

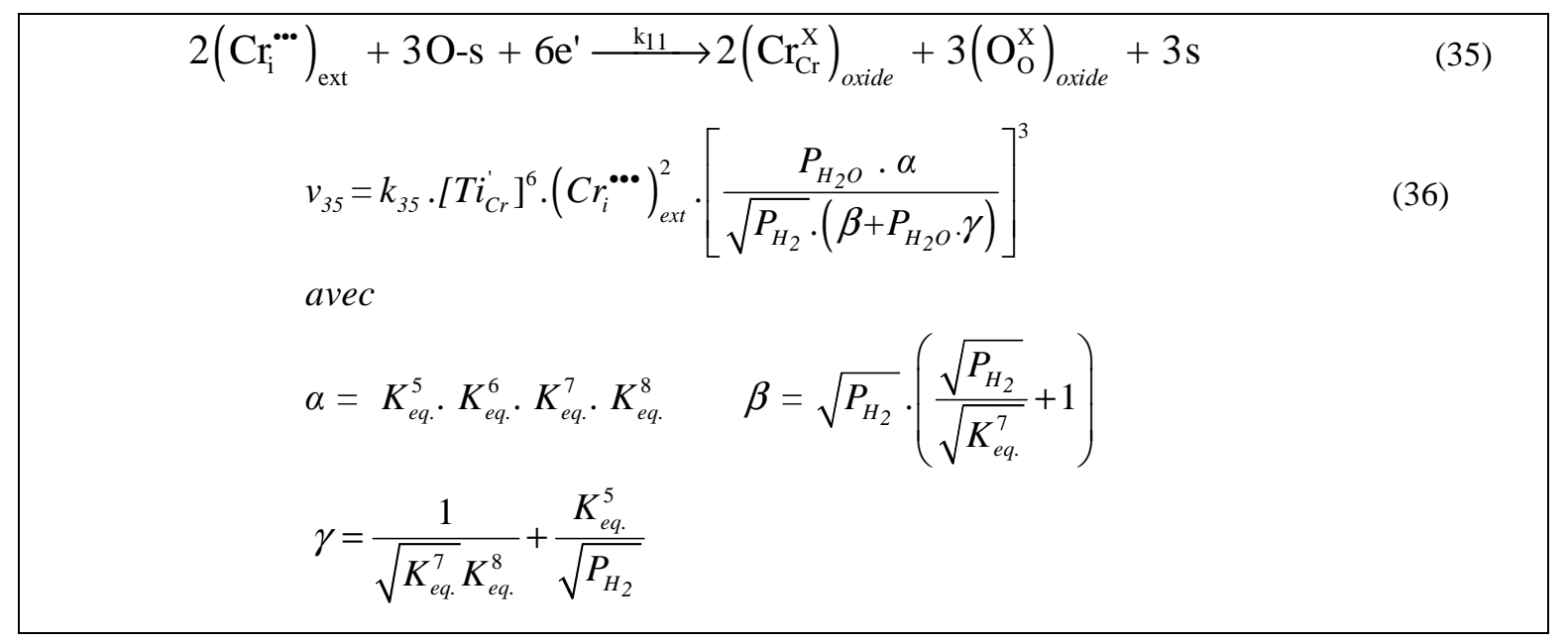

From Eq. (36), in order to observe an increase of the oxidation rate with the water partial pressure, one should consider that $\beta \gg \mathrm{PH}_{2} \mathrm{O} . \gamma$,

With such an approximation, the interfacial reaction rate becomes:

$$
v_{35}=k_{35} \cdot\left[T i_{C r}^{\prime}\right]^{6} \cdot\left(C r_{i}^{\cdots \cdots}\right)_{e x t}^{2} \cdot\left[\frac{P_{H_{2} O} \cdot \alpha}{\sqrt{P_{H_{2}}} \cdot \beta}\right]^{3}
$$

As shown in Eq. (37), the interfacial reaction rate is a cubic function of $\mathrm{P}_{\mathrm{H} 2 \mathrm{O}}$ which is in good agreement with the experimental observations shown in Figure 14.

It is now interesting to compare the rates (calculated from the $\mathrm{k}_{\mathrm{l}}$ and $\mathrm{k}_{\mathrm{p}}$ constants) that would be observed if the oxidation was controlled only by one of the two steps, diffusion or interfacial reaction.

By representing on the same plot the change in, both, the diffusion rate of interstitial chromium Eq. (33) and the rate of formation of a chromia unit cell Eq. (37), two distinct kinetic behaviours can be observed depending on the water partial pressure value. On one hand, at high partial pressure of water (higher than $10 \mu \mathrm{bar}$ ), the diffusion rate of chromium interstitial has the lower value at any time (Figure 15). As a consequence, the oxidation rate of alloy 617 would be well described by a parabolic kinetics as observed experimentally. On the other hand, when exposed to a low partial pressure of water, and up to $10 \mu \mathrm{bar}$, the interfacial reaction at the gas/oxide interface between adsorbed oxygen and chromium is slower than the diffusion rate of chromium in 
the first twelve hours of oxidation (Figure 16). Nevertheless, with the oxide thickening, the rate of chromium diffusion through the oxide layer decreases progressively to become roughly equal to the interfacial reaction rate after roughly 12 hours. In that case the oxidation kinetics in the first hours of oxidation is well described by a mixed regime as observed experimentally in Figure 9. The lower the water partial pressure in impure helium, the longer is the time at which the interfacial reaction impacts on the oxidation kinetics. After about hundred hours, diffusion of cations becomes the rate limiting step and parabolic growth rate is observed.

\section{Conclusions}

Oxidation tests of alloy 617 at $850^{\circ} \mathrm{C}$ for $20 \mathrm{~h}$ under impure helium with $130 \mathrm{vpm}_{2}$ and variable partial pressures of water and carbon monoxide showed that there was a competition between $\mathrm{CO}$ and $\mathrm{H}_{2} \mathrm{O}$ for oxidizing the material. To react, the $\mathrm{CO}$ partial pressure in helium had to be much higher than the water partial pressure. It is concluded that the adsorption of $\mathrm{H}_{2} \mathrm{O}$ and $\mathrm{CO}$ molecules occurs on the same sites and that $\mathrm{H}_{2} \mathrm{O}$ is more strongly adsorbed than $\mathrm{CO}$ on the $\mathrm{Cr}_{2} \mathrm{O}_{3}$ surface. As a consequence, the higher water partial pressure, the lower surface reaction sites available for $\mathrm{CO}$.

After a transient time (about a few hours) which corresponds probably to the time for growing a complete homogeneous oxide layer on the alloy surface, $\mathrm{H}_{2} \mathrm{O}$ becomes the only molecule to oxidize the surface. By analyzing the variations of $\mathrm{H}_{2} \mathrm{O}$ and $\mathrm{CO}$ consumption rates with time, a reaction mechanism for each molecule could be proposed and compared to experimental kinetic data. By taking several assumptions, it was found that, at a water partial pressure below $10 \mu$ bar, the oxidation kinetic regime by $\mathrm{H}_{2} \mathrm{O}$ was mixed with an interfacial and a diffusional reaction. The interfacial step was only rate limiting in the first tenths hours of oxidation. At higher $\mathrm{H}_{2} \mathrm{O}$ partial pressures, the kinetic regime was only diffusional from the very beginning of the exposure.

Whatever the helium composition, the oxidation kinetics was well defined by considering the outward diffusion of interstitial chromium cations in the oxide layer. In that case, the long-term oxidation rate was found not to depend on the $\mathrm{H}_{2} \mathrm{O}$ partial pressure in helium. 


\section{References}

[1] K.G.E. Brenner, L.W. Graham, The Development And Application Of A Unified Corrosion Model For HighTemperature Gas-Cooled Reactor Systems, Nucl. Technol., 66 (1984) 404-414.

[2] H.J. Christ, U. Kunecke, K. Meyer, H.G. Sockel, High-Temperature Corrosion Of The Nickel-Based Alloy Inconel-617 In Helium Containing Small Amounts Of Impurities, Materials Science And Engineering, 87 (1987) 161-168.

[3] M. Shindo, W.J. Quadakkers, H. Schuster, Corrosion Behavior Of High-Temperature Alloys In Impure Helium Environments, Journal Of Nuclear Materials, 140 (1986) 94-105.

[4] W.J. Quadakkers, H. Schuster, Thermodynamic And Kinetic Aspects Of The Corrosion Of HighTemperature Alloys In High-Temperature Gas-Cooled Reactor Helium, Nucl. Technol., 66 (1984) 383-391. [5] W.J. Quadakkers, H. Schuster, Corrosion Of High-Temperature Alloys In The Primary Circuit Helium Of High-Temperature Gas-Cooled Reactors.1. Theoretical Background, Werkst. Korros.-Mater. Corros., 36 (1985) 141-150.

[6] W.J. Quadakkers, Corrosion Of High-Temperature Alloys In The Primary Circuit Helium Of HighTemperature Gas-Cooled Reactors.2. Experimental Results, Werkst. Korros.-Mater. Corros., 36 (1985) 335-347.

[7] C. Cabet, J. Chapovaloff, F. Rouillard, G. Girardin, D. Kaczorowski, K. Wolski, M. Pijolat, High temperature reactivity of two chromium-containing alloys in impure helium, Journal Of Nuclear Materials, 375 (2008) 173-184.

[8] F. Rouillard, C. Cabet, K. Wolski, M. Pijolat, Oxidation of a chromia-forming nickel base alloy at high temperature in mixed diluted CO/H2O atmospheres, Corrosion Science, 51 (2009) 752-760.

[9] F. Rouillard, C. Cabet, K. Wolski, M. Pijolat, Oxide-layer formation and stability on a nickel-base alloy in impure helium at high temperature, Oxidation Of Metals, 68 (2007) 133-148.

[10] F. Rouillard, C. Cabet, K. Wolski, A. Terlain, M. Tabarant, M. Pijolat, F. Valdivieso, High temperature corrosion of a nickel base alloy by helium impurities, Journal Of Nuclear Materials, 362 (2007) 248-252.

[11] F. Rouillard, C. Cabet, S. Gosse, K. Wolski, M. Pijolat, Thermodynamic modelling of the destruction of the surface $\mathrm{Cr}(2) \mathrm{O}(3)$ on Alloy 230 in the impure helium atmosphere of a Gas Cooled Reactor, High Temperature Corrosion And Protection Of Materials 7, Pts 1 And 2, 595-598 (2008) 429-438.

[12] J. Chapovaloff, D. Kaczorowski, G. Girardin, Parameters governing the reduction of oxide layers on Inconel 617 in impure VHTR He atmosphere, Mater. Corros., 59 (2008) 584-590.

[13] J. Chapovaloff, G. Girardin, D. Kaczorowski, K. Wolski, M. Pijolat, Influence of Al on the High Temperature corrosion behaviour of Inconel 617 in VHTR primary coolant atmosphere, Materials Science Forum, 595-598 (2008) 439-448.

[14] C. Cabet, G. Girardin, F. Rouillard, J. Chapovaloff, K. Wolski, M. Pijolat, Comparison of the high temperature surface reactivity in impure helium of two materials for gas cooled reactors, Materials Science and Forum, 595-598 (2008) 439-448.

[15] D. Kumar, R.R. Adharapurapu, T.M. Pollock, G.S. Was, High-Temperature Oxidation of Alloy 617 in Helium Containing Part-Per-Million Levels of CO and $\mathrm{CO}(2)$ as Impurities, Metall. Mater. Trans. A-Phys. Metall. Mater. Sci., 42A (2011) 1245-1265.

[16] R.R. Adharapurapu, D. Kumar, J. Zhu, C.J. Torbet, G.S. Was, T.M. Pollock, Chromia-Assisted Decarburization of W-Rich Ni-Based Alloys in Impure Helium at 1273 K (1000 degrees C), Metall. Mater. Trans. A-Phys. Metall. Mater. Sci., 42A (2011) 1229-1244.

[17] K. Mo, G. Lovicu, H.M. Tung, X.A. Chen, J.F. Stubbins, High Temperature Aging and Corrosion Study on Alloy 617 and Alloy 230, J. Eng. Gas. Turbines Power-Trans. ASME, 133 (2011).

[18] J. Chapovaloff, D. Kazarowski, P. Combrade, M. Pijolat, K. Wolski, Assessing the kinetics of high temperature oxidation of Inconel 617 in impure helium by coupling TGA and GPC analysis, Oxidation of Metals, (2012).

[19] Y. Shida, G.C. Wood, F.H. Stott, D.P. Whittle, B.D. Bastow, Intergranular oxidation and internal void formation in Ni-40\% Cr alloys, Corrosion Science, 21 (1981) 581.

[20] I. Langmuir, Journal of American Chemical Society, 40 (1918) 1361.

[21] Q. Lu, G. Hultquist, A Comparison Of The Initial Reaction Of Pure Fe, Cr And Al In (H216o/H218o/O2)O-16-O-18 Gas-Mixtures At 300-730 K Studied In-Situ With Sims, Corrosion Science, 36 (1994) 927-939.

[22] B. Delmon, Introduction à la cinétique hétérogène, Paris, 1969. 
[23] C. Anghel, E. Hornlund, G. Hultquist, M. Limback, Gas phase analysis of CO interactions with solid surfaces at high temperatures, Applied Surface Science, 233 (2004) 392-401.

[24] Y. Wouters, A. Galerie, J.-P. Petit, Thermal oxidation of titanium by water vapour, Solid State Ion., 104 (1997) 89.

[25] D. Monceau, B. Pieraggi, Determination of parabolic rate constants from a local analysis of mass-gain curves, Oxidation of Metals, 50 (1998) 477-493.

[26] B.E. Deal, A.S. Grove, General Relationship For Thermal Oxidation Of Silicon, J. Appl. Phys., 36 (1965) 3770-\&.

[27] K. Wagner, Zeitschrift Für Physikalische, B21 (1933) 25.

[28] P. Sarrazin, A. Galerie, J. Fouletier, Les mécanismes de la corrosion sèche. Une approche cinétique, Les Ulis, 2000.

[29] F.A. Kroger, H.J. Vink, Relations Between The Concentrations Of Imperfections In Crystalline Solids, Solid State Physics-Advances In Research And Applications, 3 (1956) 307-435.

[30] J. Chapovaloff, Etude des mécanismes de corrosion de l'Inconel 617 dans le circuit des Réacteurs à Haute Température refroidis par l'hélium, in: Science des Matériaux, Ecole Nationale Supérieure des Mines de St Etienne, St Etienne, 2009, pp. 198.

[31] A. Holt, P. Kofstad, Electrical conductivity of Cr2O3 doped with TiO2, Solid State Ion., 117 (1999) 21-25. 


\section{Acknowledgements}

The authors would like to thank AREVA NP for financial supports. 
Figure 1 : Scheme of the experimental facility used for carrying out the oxidation test in well-controlled $\mathrm{CO}-\mathrm{H}_{2}-$ $\mathrm{H}_{2} \mathrm{O}$ mixture in helium and measuring the gas reactions and the mass gain increase [18].

Figure 2: Evolution of the gas phase content $\left(\mathrm{H}_{2} \mathrm{O}, \mathrm{H}_{2}\right.$ and $\left.\mathrm{CO}\right)$ and mass gain during the oxidation test He$14 \mathrm{CO}-130 \mathrm{H}_{2}-4 \mathrm{H}_{2} \mathrm{O}$ for $20 \mathrm{hrs}$ at $850^{\circ} \mathrm{C}$ measured between inlet 2 and inlet 3 (Figure 1).

Figure 3: Experimental mass gain ( $m(\exp ))$ compared to the total mass gain calculated from $\mathrm{H}_{2}$ production (Reaction (1)) and CO consumption (Reaction (2)) measured by GPC during corrosion test at $850^{\circ} \mathrm{C}$ for $20 \mathrm{hrs}$ under $\mathrm{He}-14 \mathrm{CO}-130 \mathrm{H}_{2}-4 \mathrm{H}_{2} \mathrm{O}$.

Figure 4 : FESEM images of Alloy 617's cross section and Alloy 617's surface after corrosion test at $850^{\circ} \mathrm{C}$ for $20 \mathrm{~h}$ under $\mathrm{He}-14 \mathrm{CO}-130 \mathrm{H}_{2}-4 \mathrm{H}_{2} \mathrm{O}$.

Figure 5 : Evolution of the $\mathrm{CO}$ consumption rate as a function of time in corrosion tests with different $\mathrm{CO}$ amount in $\mathrm{He}-130 \mathrm{H}_{2}-5 \mathrm{H}_{2} \mathrm{O}$.

Figure 6: Maximum CO consumption rate as a function of water partial pressure in $\mathrm{He}-14 \mathrm{CO}-130 \mathrm{H}_{2}$

Figure 7 : Mass gain of alloy 617 measured by thermobalance as a function of time for different water content in $\mathrm{He}-14 \mathrm{CO}-130 \mathrm{H}_{2}$.

Figure 8 : Variation of the maximum CO consumption rate as a function of CO partial pressure (a) and as a function of water partial pressure $\left(\mathrm{P}_{\mathrm{CO}}=15 \mu \mathrm{bar}\right)(\mathrm{b})$ in impure helium and fitting curves by Eq. (19).

Figure 9 : Mass gain due to the reaction of $4 \mu$ bar $\mathrm{H}_{2} \mathrm{O}$ with alloy 617 as a function of time fitted by (a) the parabolic law and (b) the complete parabolic law. In case (b), $\mathrm{k}_{\mathrm{p}}$ and $\mathrm{k}_{1}$ are found to be equal to $8.610^{-6}$ $\mathrm{mg}^{2} / \mathrm{cm}^{4} / \mathrm{min}$ and $8.510^{-5} \mathrm{mg} / \mathrm{cm}^{2} / \mathrm{min}$ respectively.

Figure 10 : Variation of the diffusional rate constant $k_{p}$ as function of water partial pressure.

Figure 11: Variation of the interfacial rate constant $k_{l}$ as function of water partial pressure.

Figure 12 : Point defects which could be formed when considering outwards chromium rich oxide layer.

Figure 13: Scheme of the oxidation mechanism of alloy 617 by $\mathrm{H}_{2} \mathrm{O}$ in impure helium with the different reaction steps

Figure 14: Experimental values of $\mathrm{k}_{\mathrm{l}}$ as a function of $\mathrm{P}_{\mathrm{H} 2 \mathrm{O}}$ and its fitting by Eq. (37)

Figure 15 : Comparison between the rate of interfacial reaction and the rate of diffusion involved in the oxidation of alloy 617 in $\mathrm{He}-15 \mathrm{CO}-130 \mathrm{H}_{2}$ with $21 \mathrm{H}_{2} \mathrm{O}$.

$\mathrm{k}_{1}=1.4 \cdot 10^{-6} *(21)^{3}=0.013$

Figure 16 : Comparison between the rate of interfacial reaction and the rate of diffusion involved in the oxidation of alloy 617 in $\mathrm{He}-15 \mathrm{CO}-130 \mathrm{H}_{2}$ with $4 \mathrm{H}_{2} \mathrm{O}$.

$\mathrm{k}_{1}=1.4 \cdot 10^{-6} *(4)^{3}=910^{-5}$ 
Figure 1

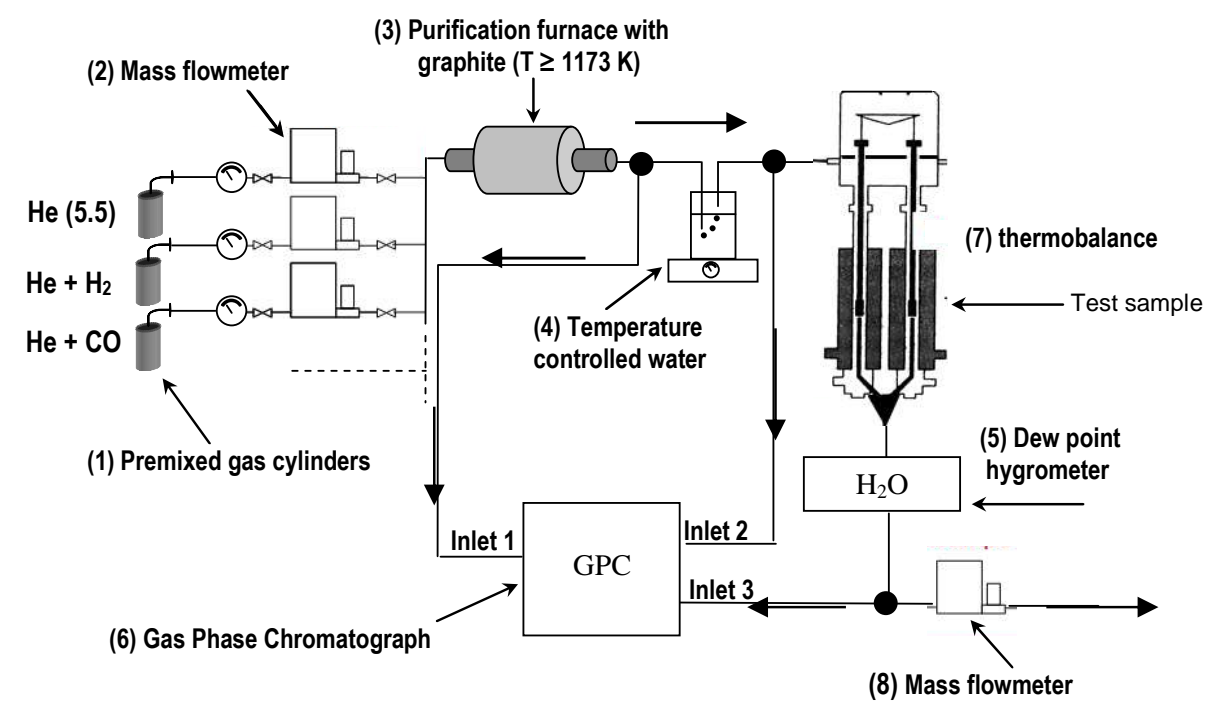


Figure 2

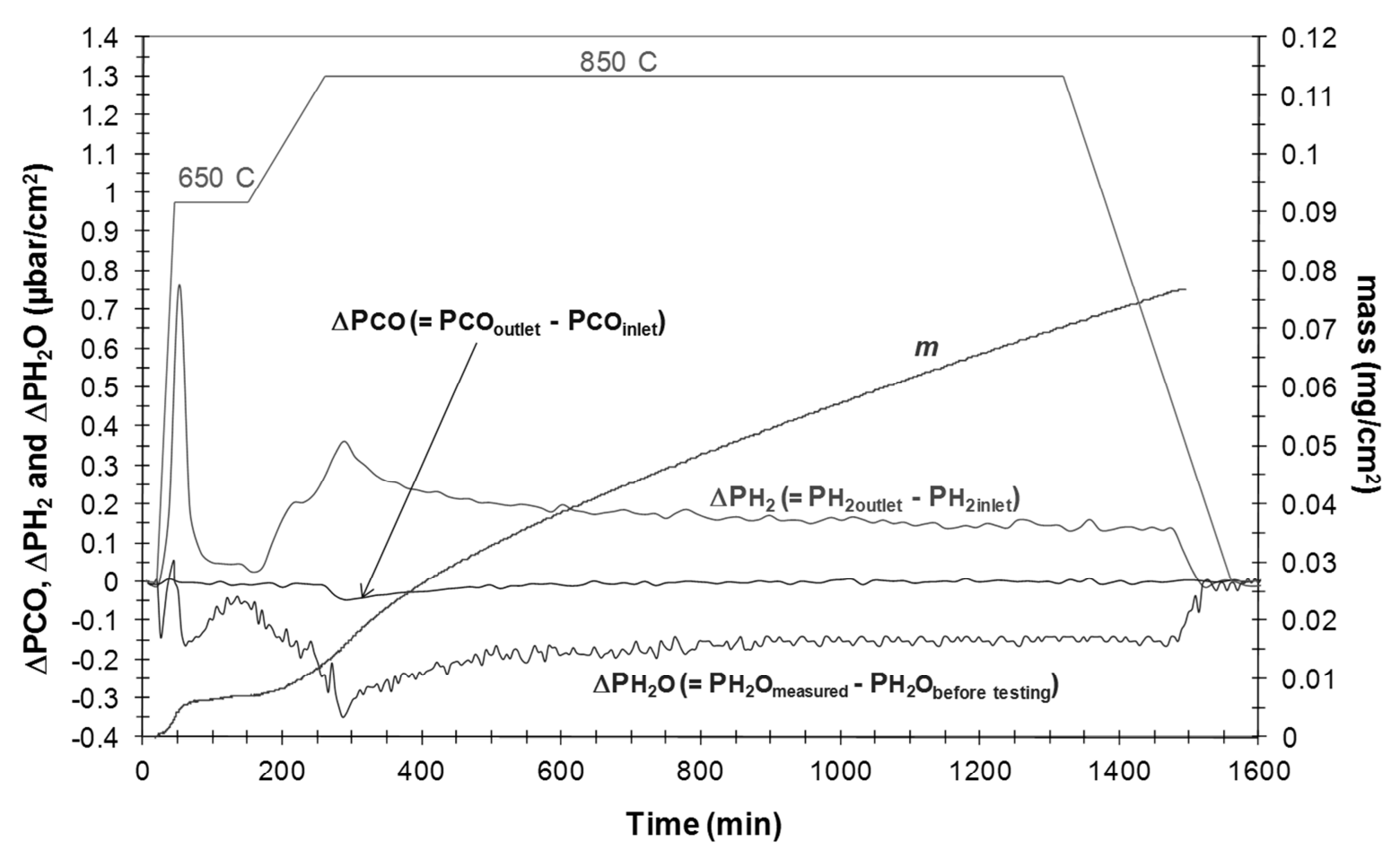


Figure 3

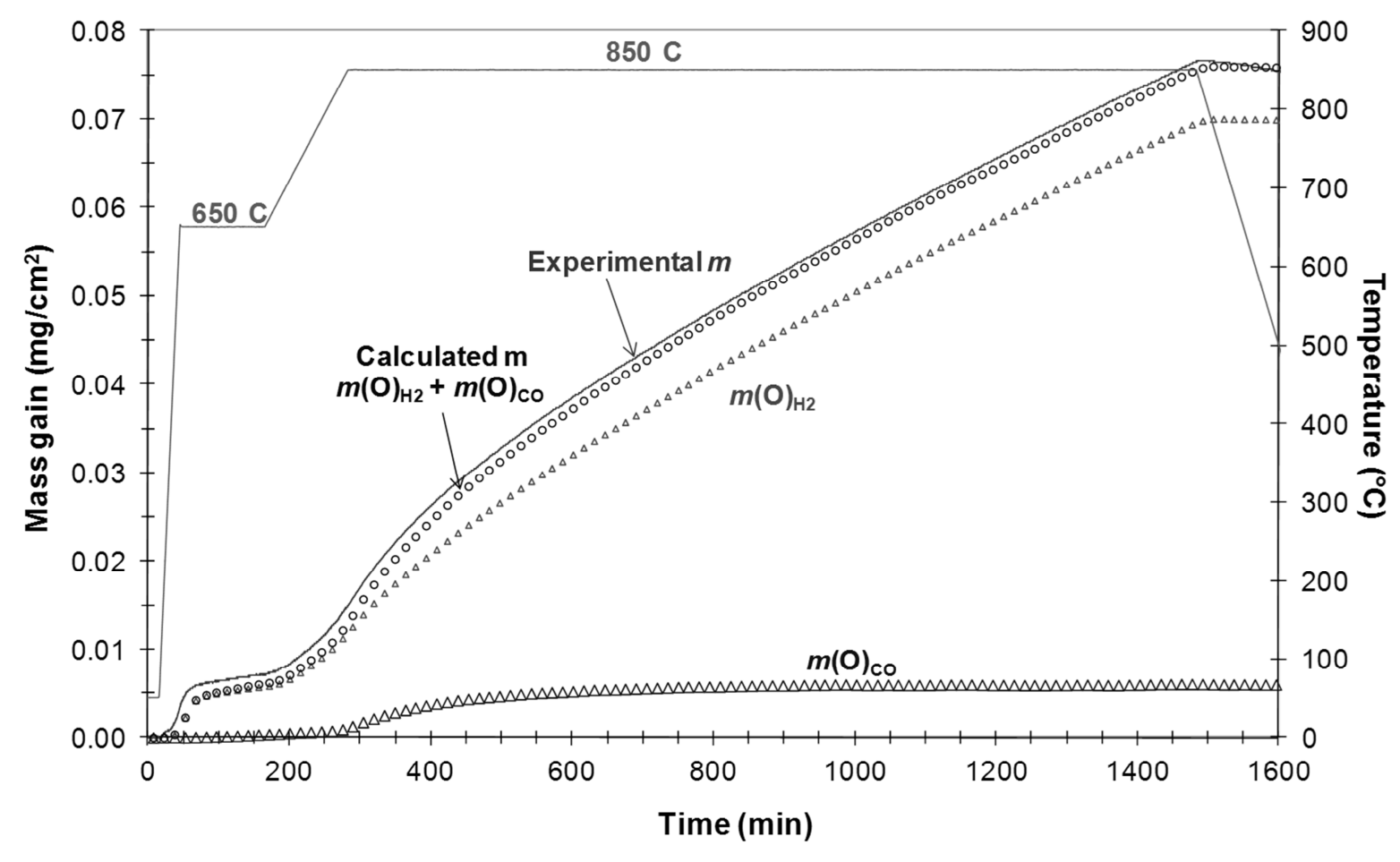


Figure 4

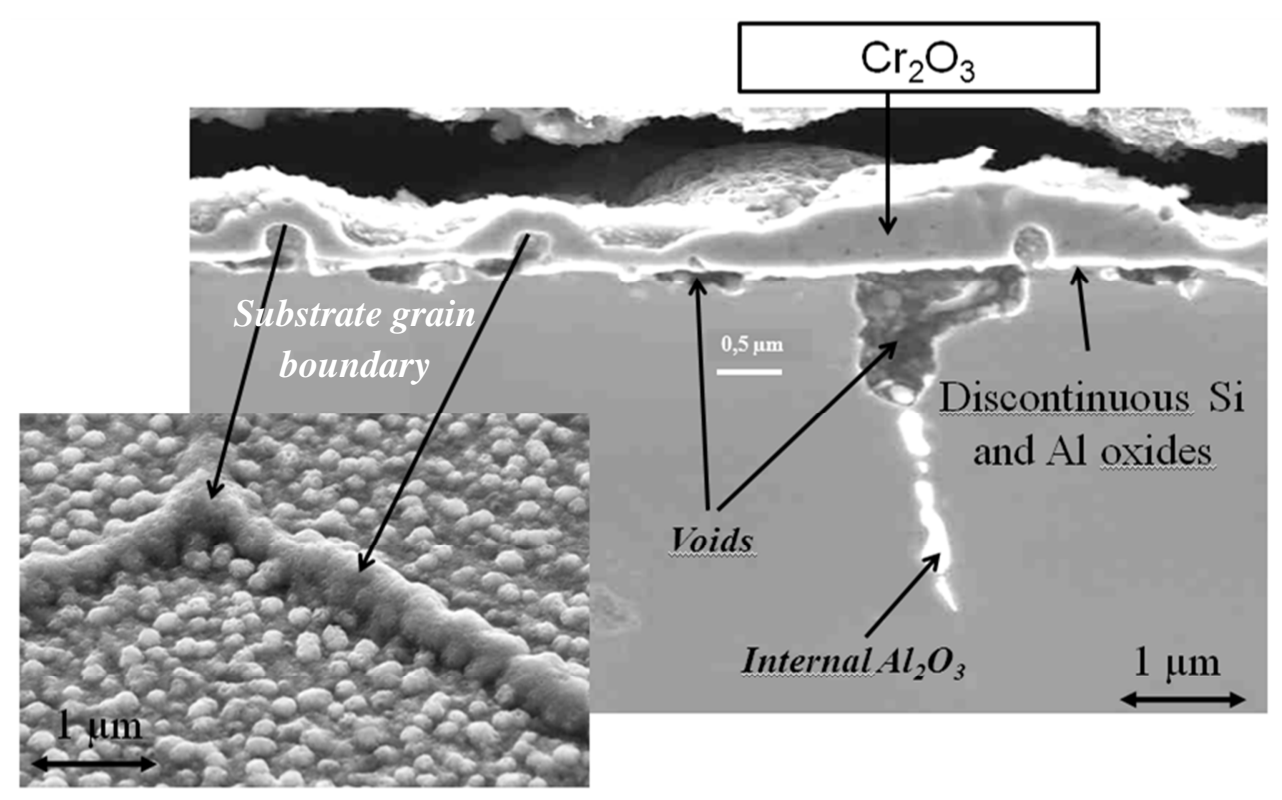


Figure 5

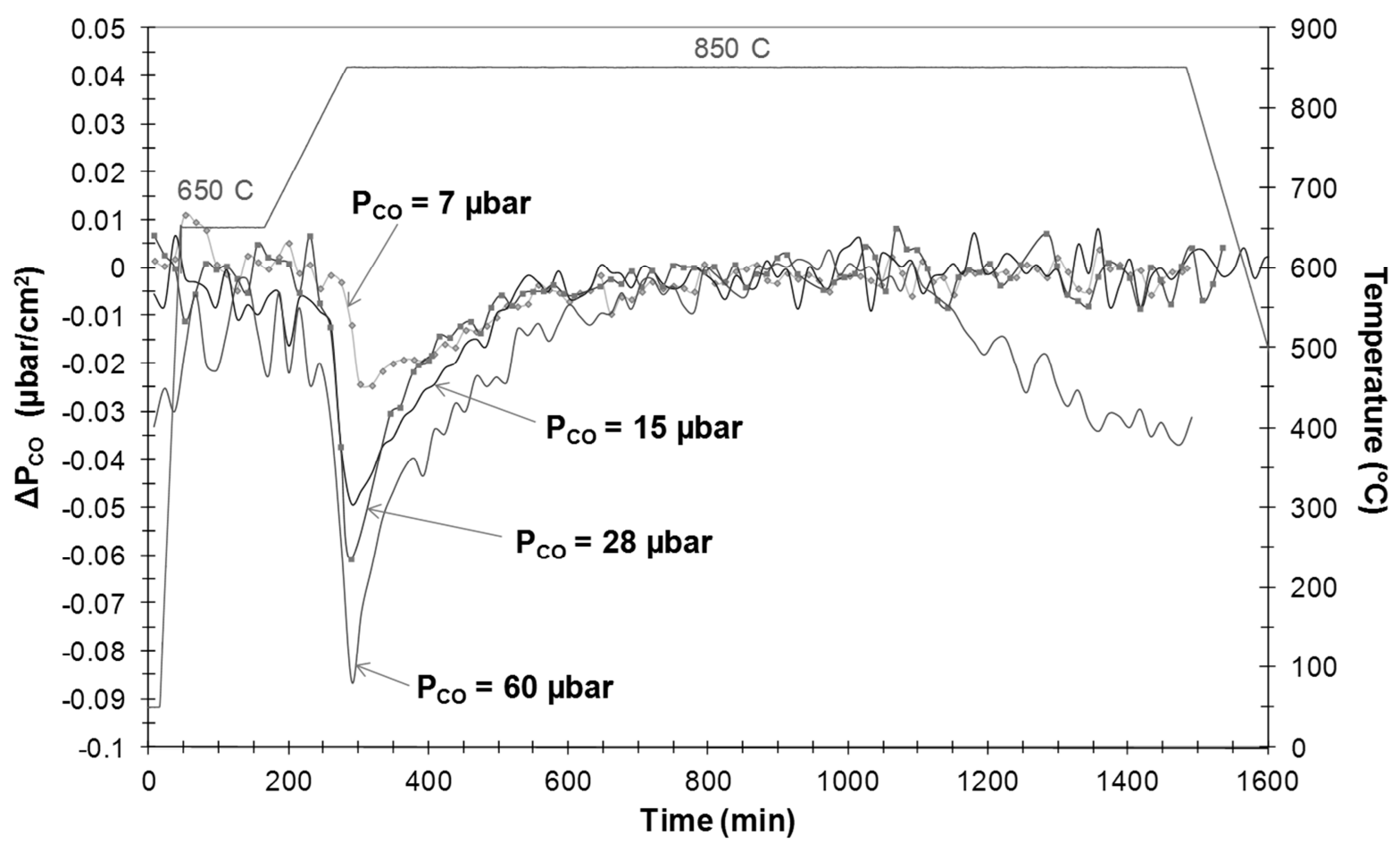


Figure 6

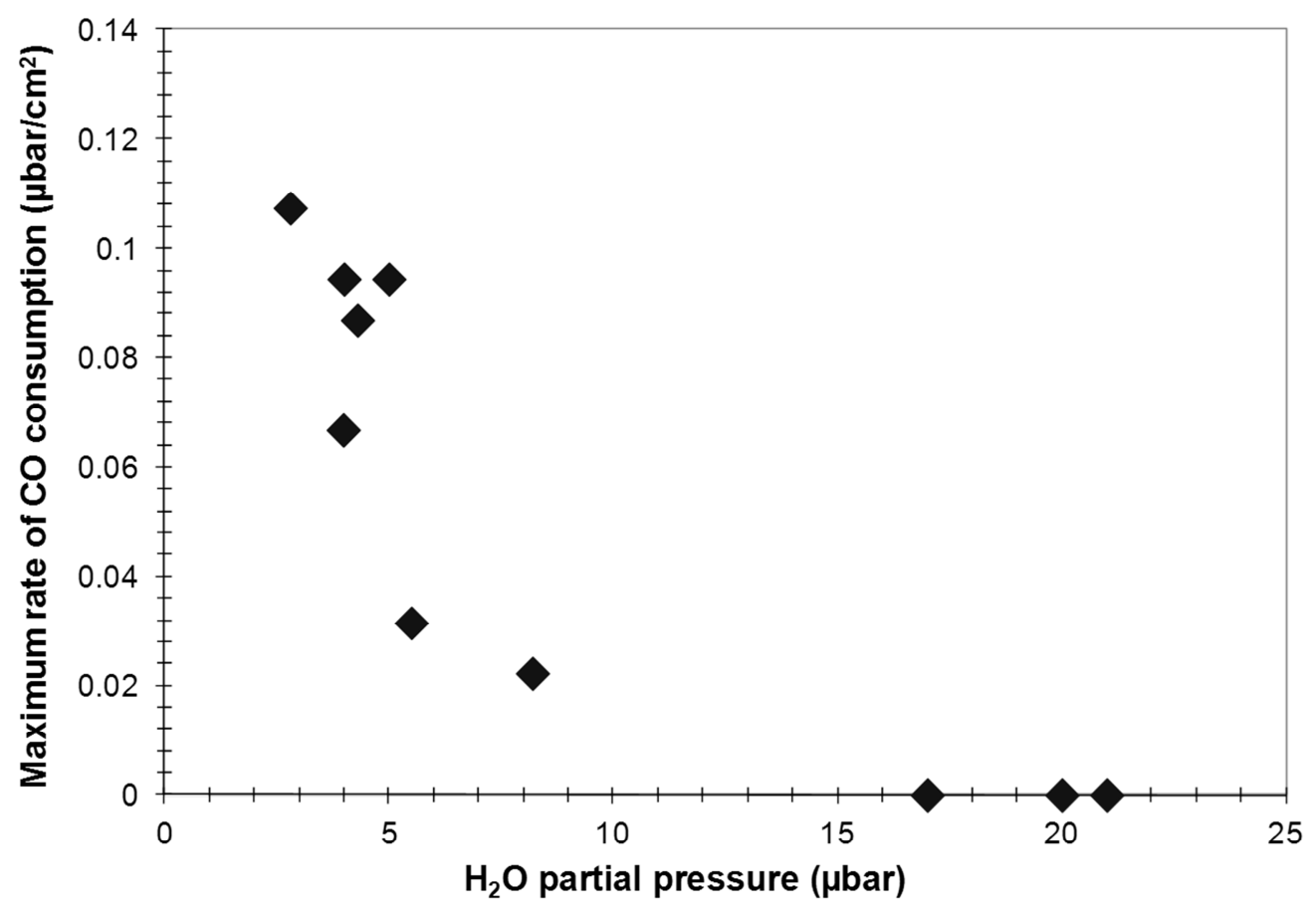


Figure 7

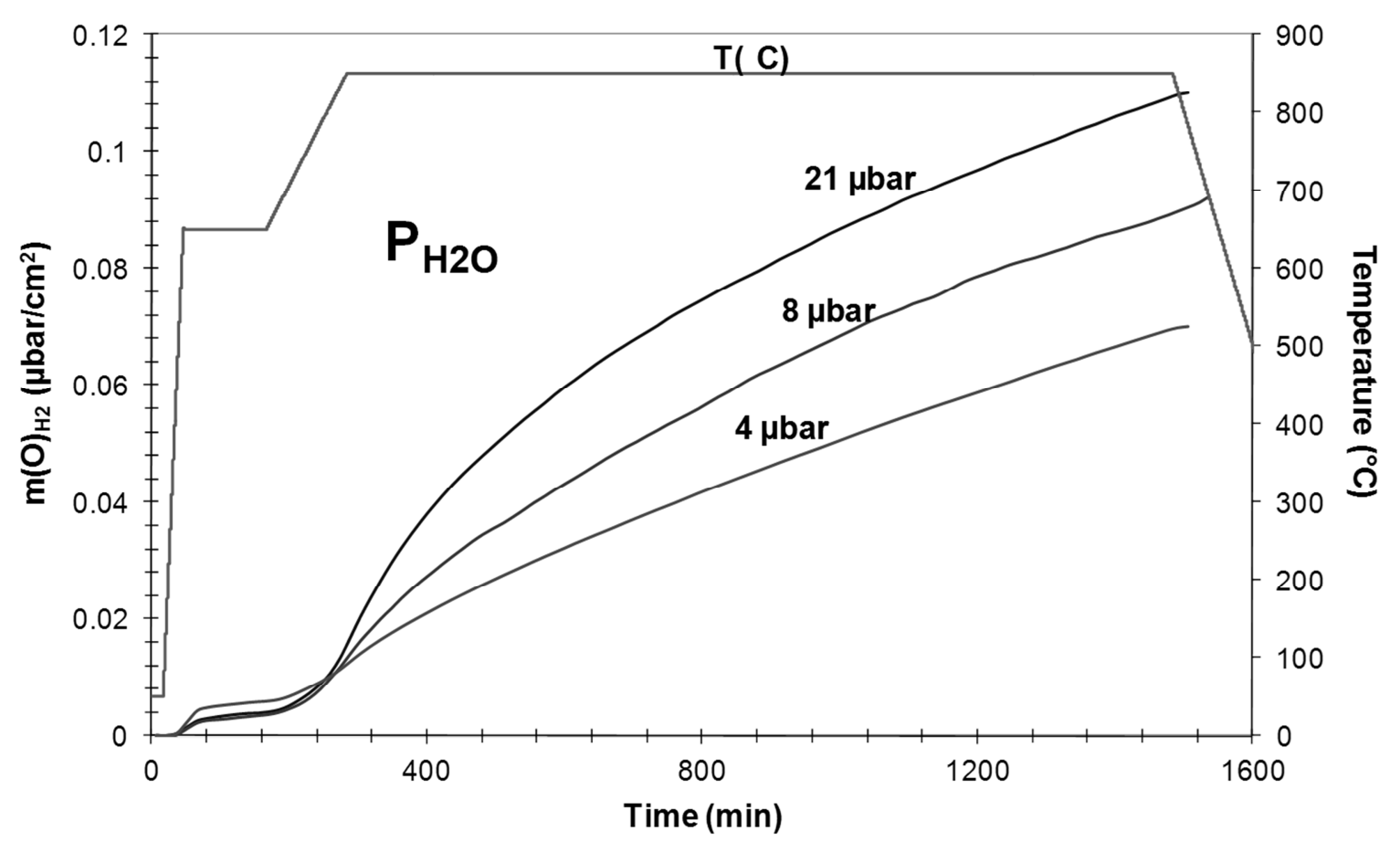


Figure 8

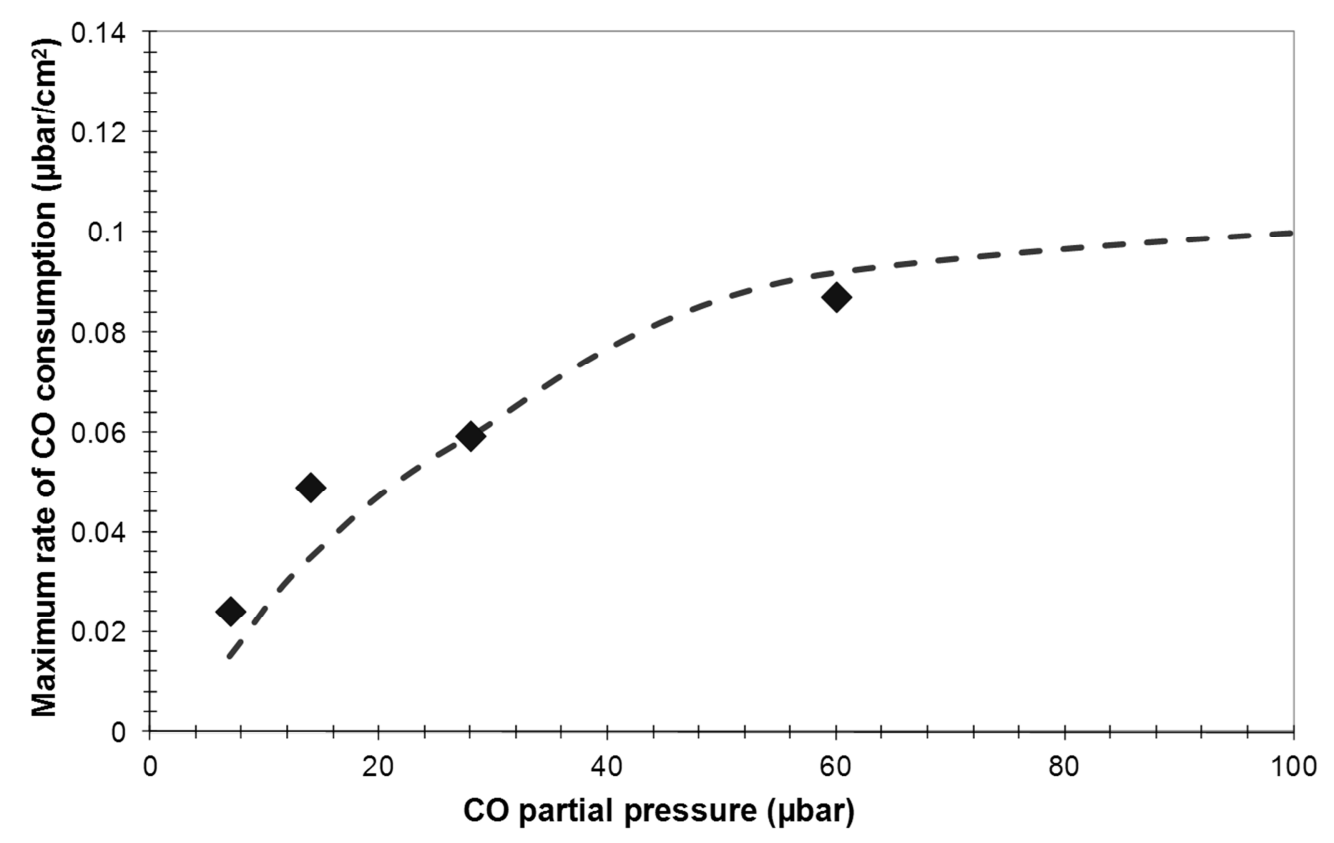

(a)

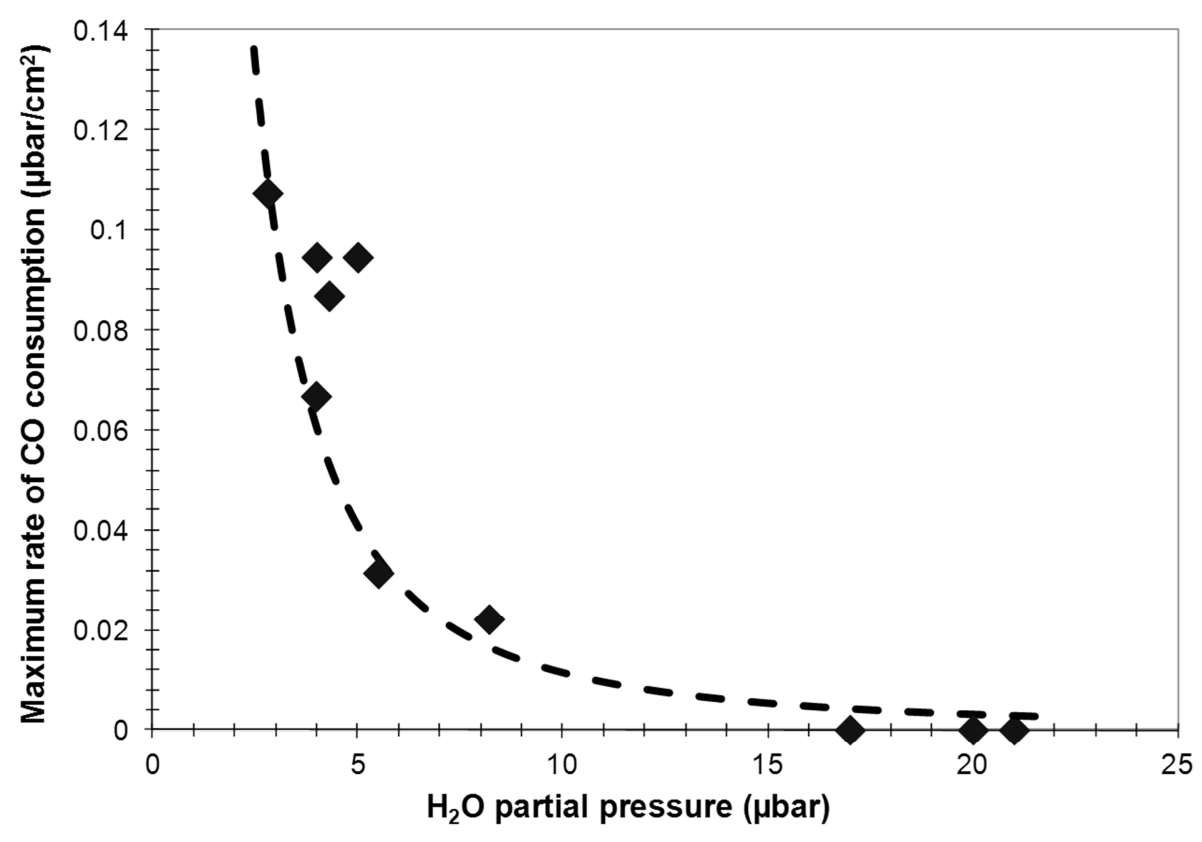

(b) 
Figure 9

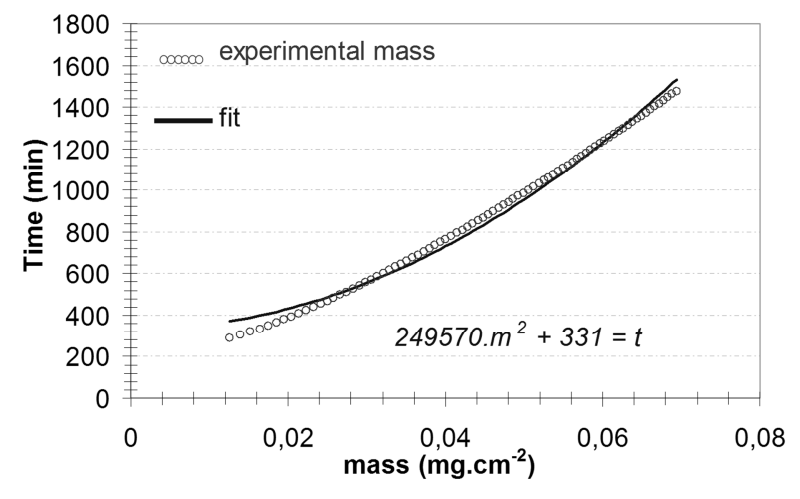

(a)

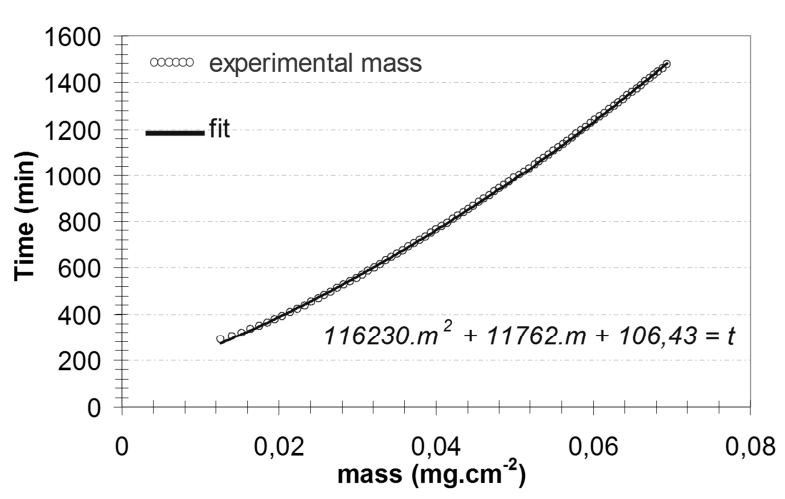

(b) 
Figure 10

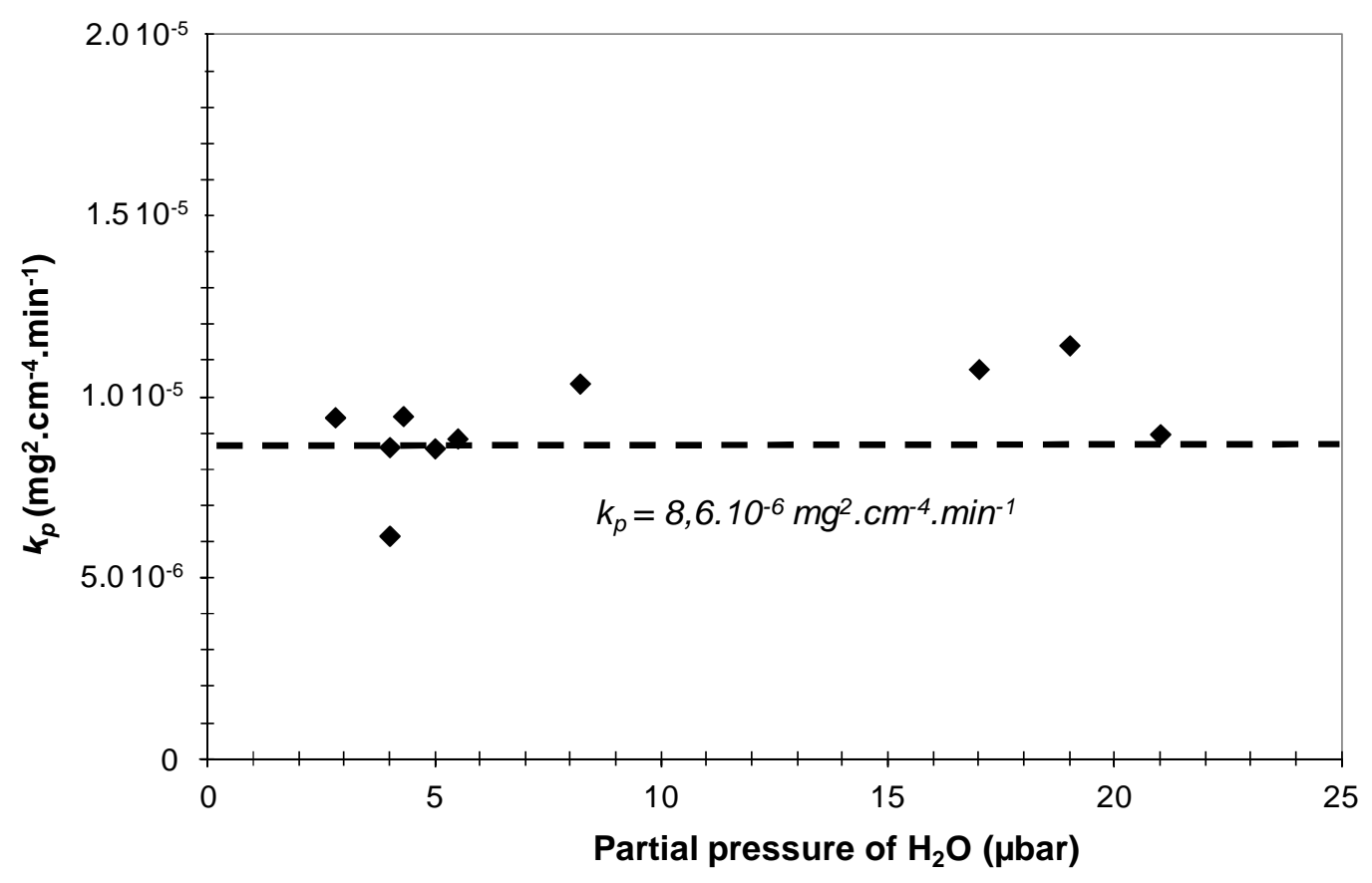


Figure 11

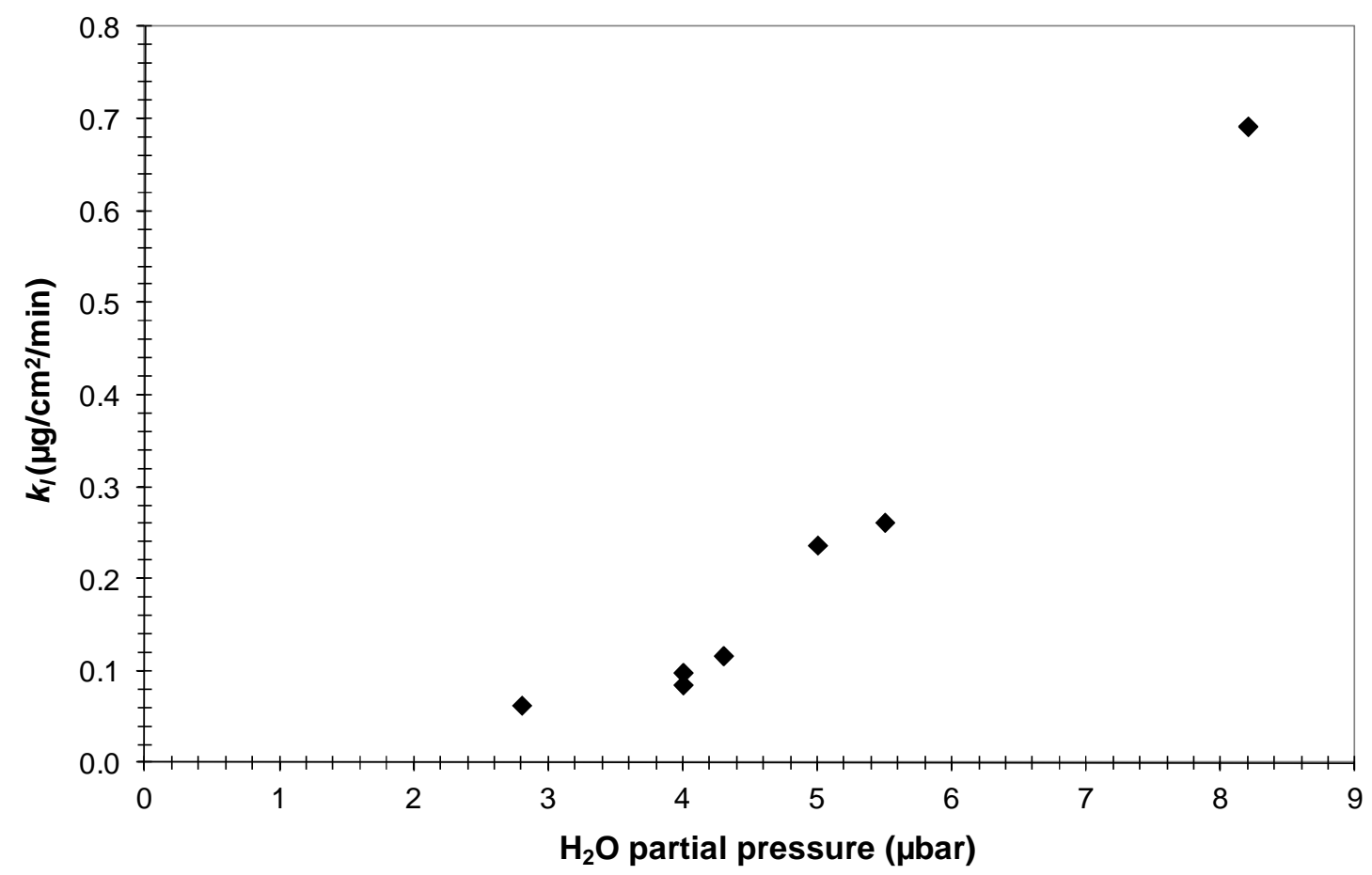


Figure 12

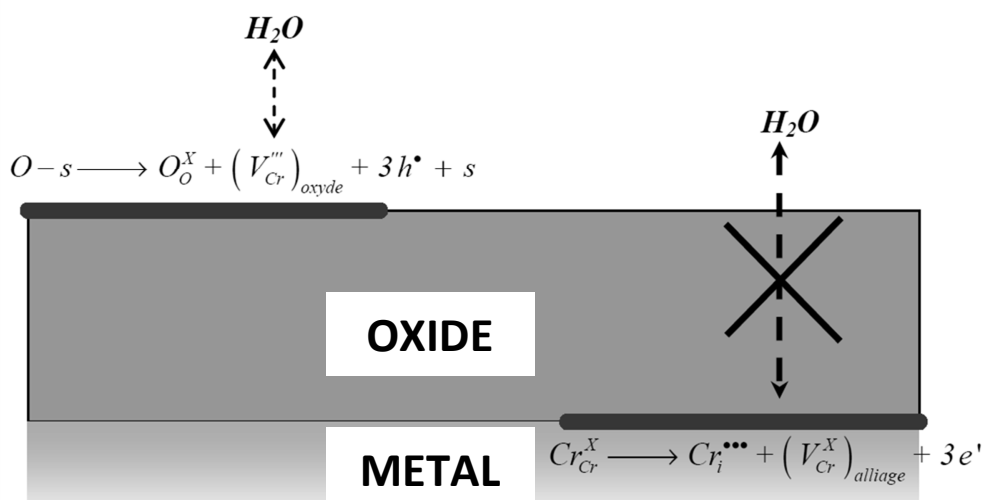


Figure 13

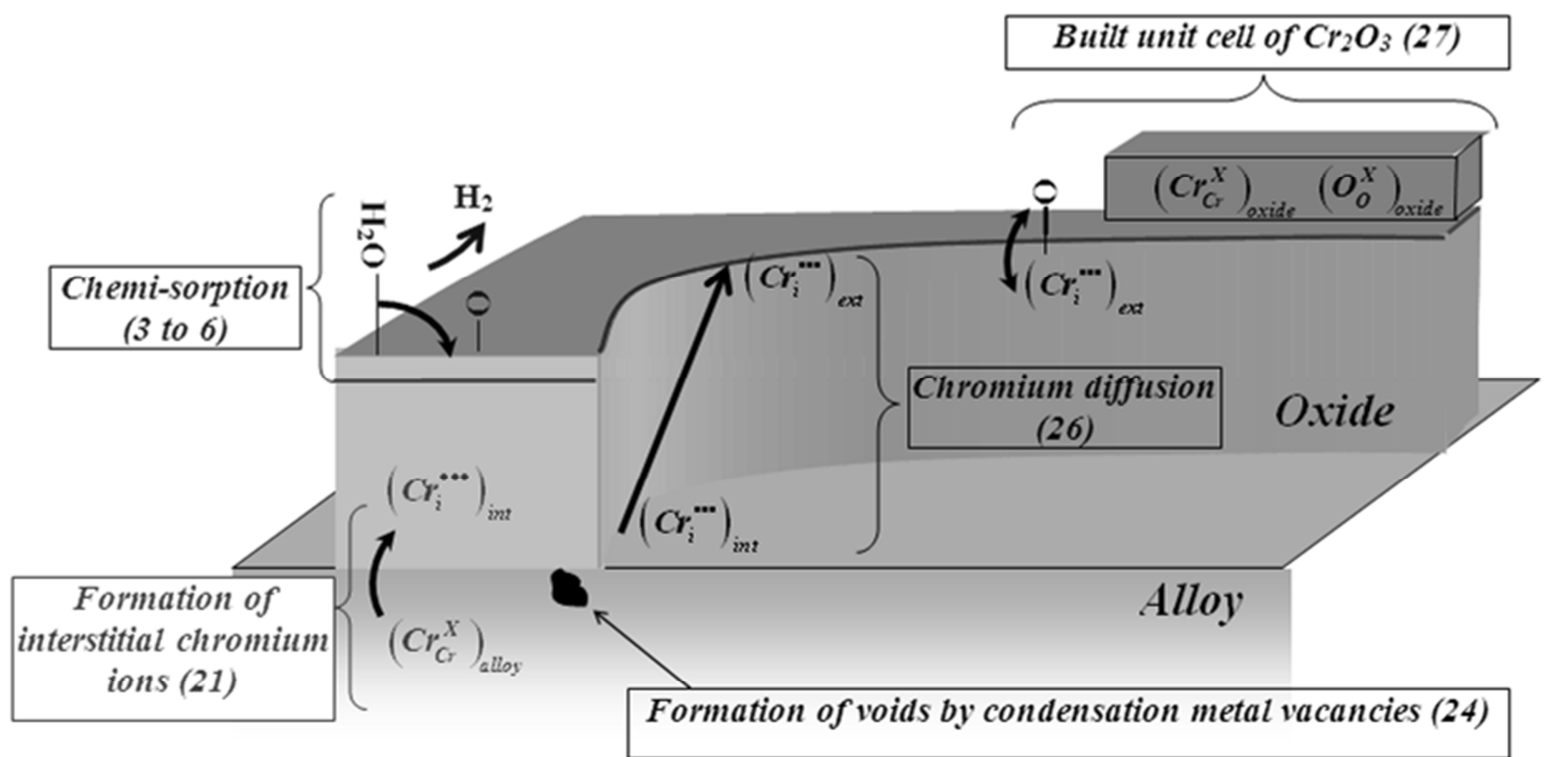


Figure 14

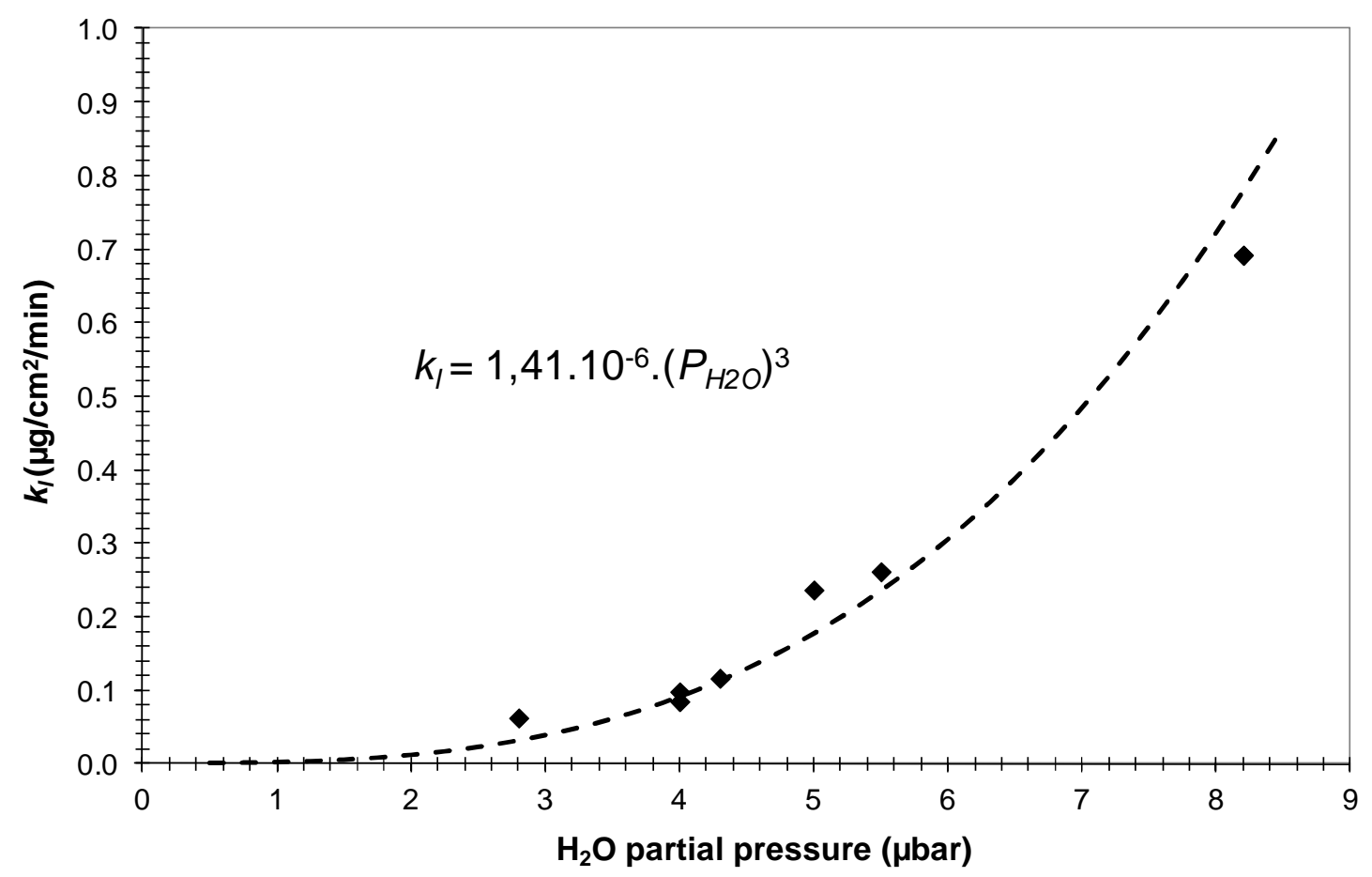


Figure 15

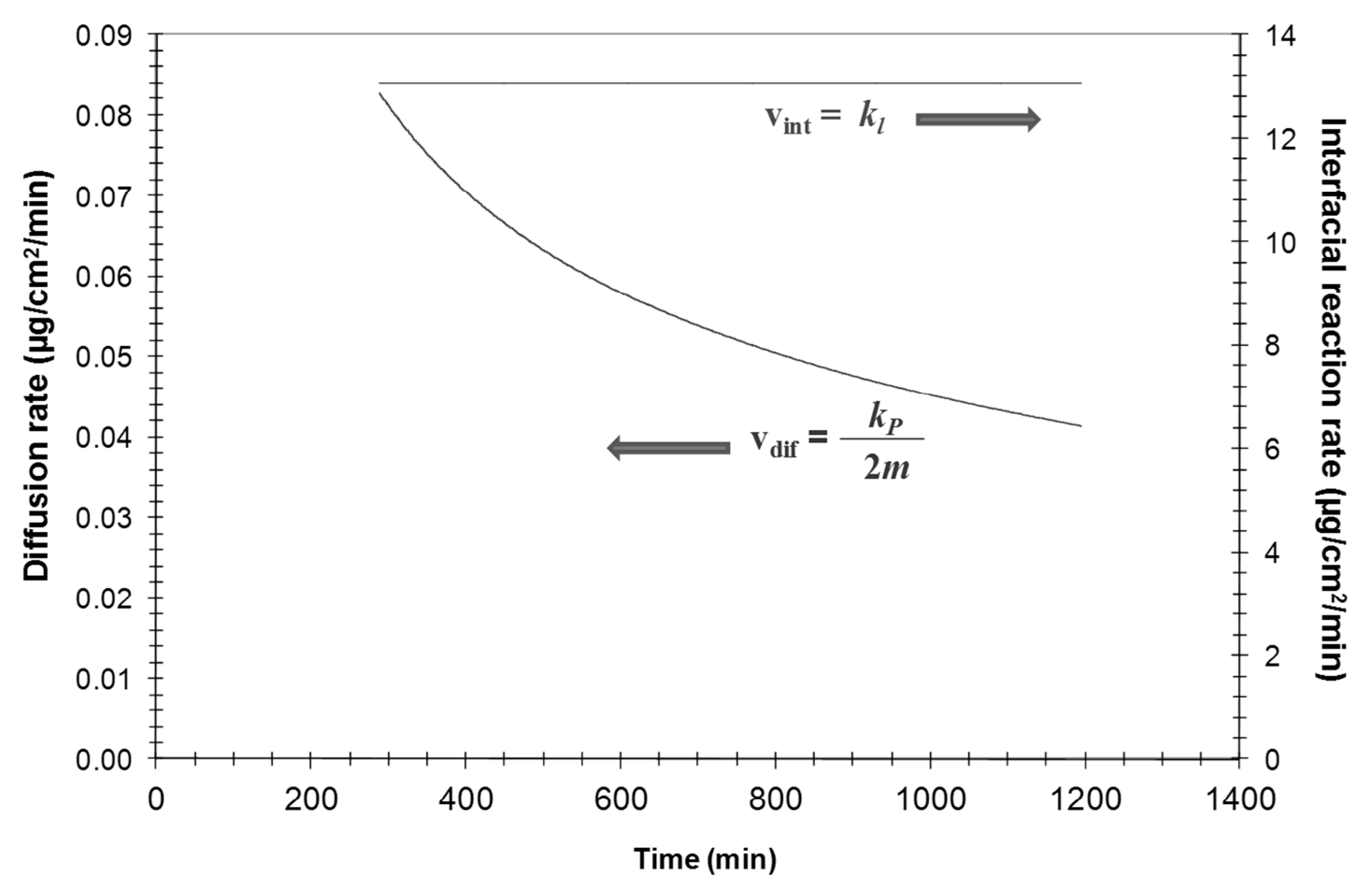


Figure 16

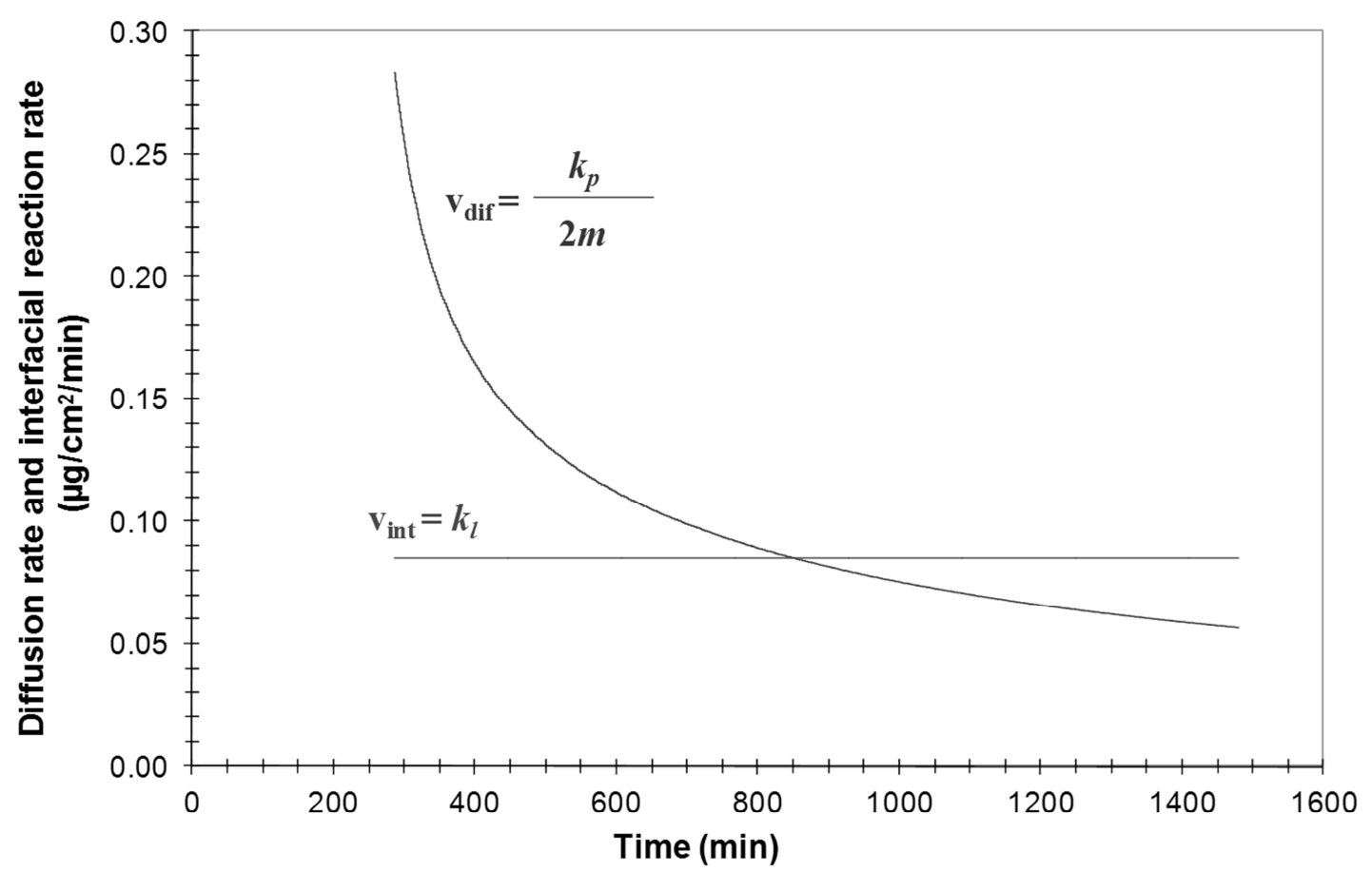


Table 1

Alloy composition (wt \%)

\begin{tabular}{|lcccccccccc|}
\hline & Ni & Cr & Co & Mo & Al & Fe & Mn & Si & C \\
\hline Alloy $617^{1}$ & Bal & 21.6 & 12.0 & 9.2 & 1.0 & 1.0 & 0.1 & 0.2 & 0.06 \\
\hline
\end{tabular}




\section{Table 2}

Reaction steps for adsorption and dissociation of $\mathrm{H}_{2} \mathrm{O}$ and $\mathrm{CO}$ with $\mathrm{k}_{\mathrm{i}}$ the constant rates of the elemental semi reaction and $K_{e q .}^{i}$ the equilibrium constant of reaction step i.

\begin{tabular}{|c|c|c|c|}
\hline Semi reaction & & Equilibrium constant & \\
\hline $\mathrm{H}_{2} \mathrm{O}+\mathrm{s} \stackrel{\mathrm{k}_{3}}{\longrightarrow} \mathrm{H}_{2} \mathrm{O}-\mathrm{s}$ & (3) & $K_{\text {eq. }}^{3}=\frac{\theta_{\mathrm{H}_{2} \mathrm{O}-\mathrm{s}}}{\theta_{s} \cdot \mathrm{PH}_{2} \mathrm{O}}$ & $(10)$ \\
\hline $\mathrm{H}_{2} \mathrm{O}-\mathrm{s}+\mathrm{s} \stackrel{\mathrm{k}_{4}}{\longrightarrow} \mathrm{HO}-\mathrm{s}+\mathrm{H}-\mathrm{s}$ & (4) & $K_{e q .}^{4}=\frac{\theta_{H O-s} \cdot \theta H-s}{\theta_{s} \cdot \theta_{H_{2} O-s}}$ & (11) \\
\hline $2 \mathrm{H}-\mathrm{s} \stackrel{\mathrm{k}_{5}}{\longrightarrow} \mathrm{H}_{2}+2 \mathrm{~s}$ & (5) & $K_{e q .}^{5}=P_{H_{2}} \cdot\left(\frac{\theta_{s}}{\theta_{H-s}}\right)^{2}$ & $(12)$ \\
\hline $\mathrm{HO}-\mathrm{s}+\mathrm{s} \stackrel{\mathrm{k}_{6}}{\longrightarrow} \mathrm{H}-\mathrm{s}+\mathrm{O}-\mathrm{s}$ & (6) & $K_{e q .}^{6}=\frac{\theta_{O-s} \cdot \theta_{H-s}}{\theta_{s} \cdot \theta_{H O-s}}$ & (13) \\
\hline Semi reaction & & Equilibrium constant & \\
\hline $\mathrm{CO}+\mathrm{s} \stackrel{\mathrm{k}_{7}}{\longrightarrow} \mathrm{CO}-\mathrm{s}$ & (7) & $K_{e q .}^{7}=\frac{\theta_{C O-s}}{\theta_{s} \cdot P_{C O}}$ & (14) \\
\hline $\mathrm{CO}-\mathrm{s}+s \stackrel{\mathrm{k}_{8}}{\longrightarrow} \mathrm{C}-\mathrm{s}+\mathrm{O}-\mathrm{s}$ & (8) & $K_{e q .}^{8}=\frac{\theta_{C-s} \cdot \theta_{O-s}}{\theta_{s} \cdot \theta_{C O-s}}$ & $(15)$ \\
\hline $\mathrm{C}-\mathrm{s} \stackrel{\mathrm{k}_{9}}{\longrightarrow} \mathrm{C}+\mathrm{s}$ & (9) & $K_{e q .}^{9}=\frac{\theta_{s} \cdot a_{C}}{\theta_{C-s}}$ & (16) \\
\hline
\end{tabular}




\section{Table 3}

Reaction steps of $\mathrm{CO}$ reaction describing a decrease in $\mathrm{CO}$ consumption when the partial pressure of $\mathrm{H}_{2} \mathrm{O}$ increases or when the partial pressure of $\mathrm{CO}$ reduces.

$$
\begin{gathered}
\mathrm{CO}+\mathrm{s} \stackrel{\mathrm{k}_{7}}{\longrightarrow} \mathrm{CO}-\mathrm{s} \\
v_{7}=k_{7} \cdot \theta_{s} \cdot P_{C O}
\end{gathered}
$$

By writting $\theta s$ as a function of the equilibrium constants of the other elemental steps and by using equation 8 below:

$$
\theta_{\mathrm{H}_{2} \mathrm{O}-\mathrm{s}}+\theta_{\mathrm{HO}-\mathrm{s}}+\theta_{\mathrm{H}-\mathrm{s}}+\theta_{\mathrm{O}-\mathrm{s}}+\theta_{\mathrm{s}}+\theta_{\mathrm{CO}-\mathrm{s}}+\theta_{\mathrm{C}-\mathrm{s}}=1
$$

one ends up with

$$
v_{7}=k_{7} \cdot \frac{P_{C O} \cdot \alpha}{P_{H_{2} O} \cdot \beta \cdot \gamma}
$$

$$
\begin{aligned}
& \alpha=K_{e q \cdot}^{10} \cdot K_{e q .}^{11} \cdot \sqrt{K_{e q .}^{7}} \cdot P_{H_{2}} \quad \beta=K_{e q .}^{5} \cdot P_{H_{2}} \cdot \alpha\left(P_{H_{2}}+K_{e q .}^{6} \cdot K_{e q .}^{8}+K_{e q \cdot}^{6} \cdot \sqrt{K_{e q .}^{7}} \cdot \sqrt{P_{H_{2}}}\right) a \\
& \gamma=K_{e q \cdot}^{10} \cdot \sqrt{K_{e q .}^{7}} \cdot \sqrt{P_{H_{2}}}\left(K_{e q .}^{11} \cdot \sqrt{P_{H_{2}}}+a_{C}\right)
\end{aligned}
$$

$$
\begin{gathered}
\mathrm{CO}-\mathrm{s}+\mathrm{s} \stackrel{\mathrm{k} 8}{\longrightarrow} \mathrm{C}-\mathrm{s}+\mathrm{O}-\mathrm{s} \\
v_{8}=k_{8} \cdot \frac{P C O}{\left(\alpha \cdot P C O+\beta \cdot P H_{2} O+\gamma\right)^{2}} \\
\alpha=\frac{1}{K_{e q .}^{11}} \\
\gamma=\frac{K_{e q .}^{11} \cdot \sqrt{K_{e q .}^{7}}+a_{C} \cdot \sqrt{K_{e q .}^{7}}+K_{e q .}^{11} \cdot \sqrt{P_{H_{2}}}}{K_{e q .}^{9} \cdot\left(K_{e q .}^{11}\right)^{2} \cdot \sqrt{K_{e q .}^{7}}} \cdot \frac{K_{e q .}^{5}}{K_{e q .}^{11} \cdot P_{H_{2}}}\left(K_{e q \cdot}^{6} \cdot K_{e q \cdot}^{7} \cdot K_{e q .}^{8}+\sqrt{K_{e q .}^{7}} \cdot K_{e q .}^{6} \cdot \sqrt{P_{H_{2}}}+P_{H_{2}}\right)
\end{gathered}
$$




\section{Table A.1}

$\mathrm{A}, \mathrm{B}$ and $\mathrm{C}$ values in the kinetic law $\mathrm{Am}^{2}+\mathrm{Bm}+\mathrm{C}=\mathrm{t}$

$\mathrm{k}_{\mathrm{p}}$ : parabolic rate constant

$\mathrm{k}_{1}$ : linear rate constant

$\mathrm{t}^{*}$ and $\mathrm{m}^{*}$ are the initial conditions and account for the transient oxidation period of non parabolic kinetics : after $\mathrm{t}^{*}, \mathrm{~m}=\mathrm{m}^{*}$

\begin{tabular}{|c|c|c|}
\hline $\boldsymbol{A}$ & $\boldsymbol{B}$ & $\boldsymbol{C}$ \\
\hline$\frac{1}{k_{p}}$ & $\frac{1}{k_{l}}$ & $t^{*}-\frac{m^{*}}{k_{l}}-\frac{m^{* 2}}{k_{p}}$ \\
\hline
\end{tabular}

